\title{
Exploration of ring-closing enyne metathesis for the synthesis of azonino[5,4-b]indoles
}

\author{
Daniel Solé, ${ }^{*}$ M.-Lluïsa Bennasar, Tomàs Roca, and Magdalena Valldosera ${ }^{[a]}$
}

Dedication

\begin{abstract}
The use of the ring-closing enyne metathesis (RCEYM) as a methodology for the synthesis of the azonino[5,4-b]indole system, featuring the tricyclic substructure of the alkaloids cleavamine and quebrachamine, has been explored. Three series of enyne substrates were studied for the RCEYM reaction: in addition to the usual substrates bearing either a terminal or an internal alkyne, for the first time enynes with an alkynyl halide moiety were also considered. Although the metathesis cyclization allowed the azoninoindole nucleus to be assembled in all three series, an effective catalytic cycle was only established when using internal alkynes. On the basis of the experimental results, the "yne-then-ene" pathway seems to be the mechanism at play in these reactions.
\end{abstract}

\section{Introduction}

Indolo-fused, medium-sized nitrogen heterocycles are the basic structural units of a variety of natural products. Thus, for example, the azocino[4,3-b]indole system is present in the small group of apparicine alkaloids, ${ }^{[1]}$ while a few natural products, such as balasubramide, ${ }^{[2]}$ deoxyisoaustamide, ${ }^{[3]}$ and lundurines, ${ }^{[4]}$ embody an azocine ring $5,4-b$ fused to the indole nucleus. On the other hand, several indole alkaloids belonging to different biogenetic families (e.g., cleavamine ${ }^{[5]}$ quebrachamine $^{[6]}$ and stemmadenine ${ }^{[7]}$ ) are structurally defined by embodying an azonino[5,4-b]indole framework (Figure 1). Over the course of our long-standing interest in natural product synthesis, we have worked towards the development of a unified approach for the construction of bridged indole alkaloids. ${ }^{[8]}$ Thus, using a combination of a ring-closing metathesis (RCM) and a Heck cyclization, we have accomplished the synthesis of several indole alkaloids, ${ }^{[9]}$ including apparicine ${ }^{[10]}$ and cleavamines..$^{[11]}$ We have also recently reported our exploratory studies towards the synthesis of pericine using the sequential RCM-Heck cyclization strategy. ${ }^{[12]}$

[a] Prof. Dr. D. Solé, Prof. Dr. M.-L. Bennasar, Dr. T. Roca, M. Valldosera

Laboratori de Química Orgànica, Facultat de Farmàcia

Universitat de Barcelona

Av. Joan XXIII s/n, 08028 Barcelona, (Spain)

E-mail:dsole@ub.edu

http://www.ub.edu/farmaco/ca/quimica/listat recerca

Supporting information for this article is given via a link at the end of the document.<smiles>C=C1CN2C/C(=C/C)CC1Cc1c([nH]c3ccccc13)C2</smiles>

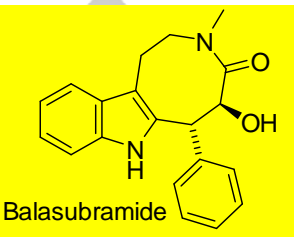<smiles>CC(C)(C)C1(C(=O)O)C=CN2C(=O)C3=CCCN3C(=O)[C@@H]2Cc2c1[nH]c1ccccc21</smiles><smiles>COc1ccc2c(c1)[C@]13CCN4CC=C[C@]4(CC[C@@]1(C)C3)C2</smiles>

Lundurine $\mathrm{B} \quad \mathrm{CO}_{2} \mathrm{Me}$

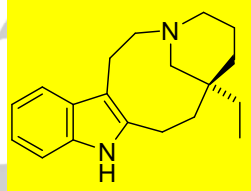

Quebrachamine

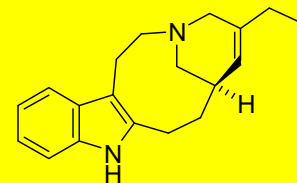

Cleavamine

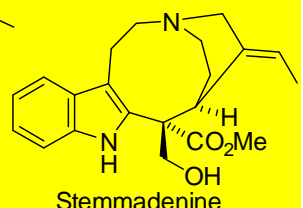

Stemmadenine
Figure 1. Indole alkaloids with a medium-sized nitrogen heterocycle.

As a continuation of our previous work, we considered applying the ring-closing metathesis strategy for the construction of azonino[5,4- $b$ ]indoles embodying a $\mathrm{C}_{5}-\mathrm{C}_{6}$ double bond with an all carbon chain at $\mathrm{C}_{5}$ (i.e. A), and featuring the central ninemembered ring present in some alkaloids such as cleavamine ${ }^{[13]}$ and quebrachamine. ${ }^{[14]}$ As depicted in Scheme 1, the assembly of the nine-membered ring would be tackled by two complementary approaches, namely a ring-closing diene metathesis and a ring-closing enyne metathesis (RCEYM).

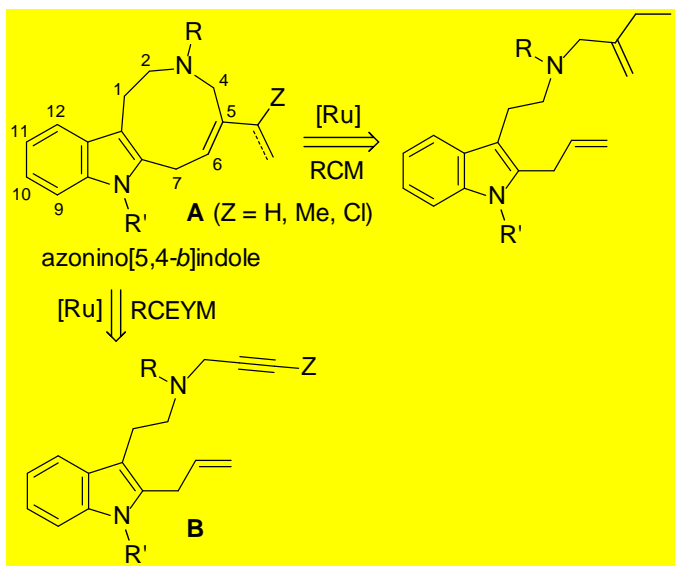

Scheme 1. Access to the azonino[5,4- b]indole $\mathbf{A}$ by metathesis reactions. 


\section{Results and Discussion}

It is widely assumed that medium-sized rings are difficult to access by direct cyclization due to entropic factors and transannular interactions in the transition state. RCM methodologies have proved to be powerful tools to address this issue, being particularly useful in the construction of eightmembered rings. ${ }^{[15]}$ However, the closure of nine-membered rings by RCM can be challenging, most reported successful cyclizations benefiting from some conformational constraints in the substrate. ${ }^{[16]}$

In the search for an RCM substrate to synthesize the desired azonino[5,4- $b$ ]indole with the $\mathrm{C}_{5}-\mathrm{C}_{6}$ double bond and an ethyl substituent at $\mathrm{C}_{5}$, diene 2 was prepared by alkylation of 2ethylallylamine ${ }^{[17]}$ with the known tosylate $1{ }^{[9 c]}$ followed by protection of the resulting secondary amine with a Boc group (Scheme 2).
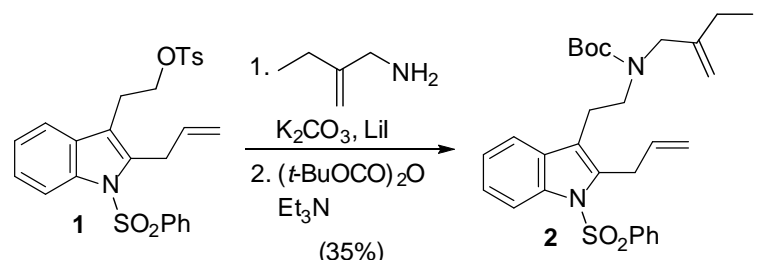

Scheme 2. Synthesis of diene 2.

Unfortunately, exposure of diene 2 to different ruthenium catalysts (second-generation Grubbs catalyst $\mathbf{G 2}$ or secondgeneration Hoveyda-Grubbs catalyst $\mathbf{H - G 2}$ in $\mathrm{CH}_{2} \mathrm{Cl}_{2}$ or toluene) did not deliver the expected nine-membered ring. In all assays, only the isomerization product $3(45-51 \%)$ and dimer $4(\approx 30 \%)$, the latter resulting from an intermolecular metathesis, were obtained (Scheme 3). The failure of the RCM reaction was attributed to the presence of a geminal disubstituted alkene unit in 2.

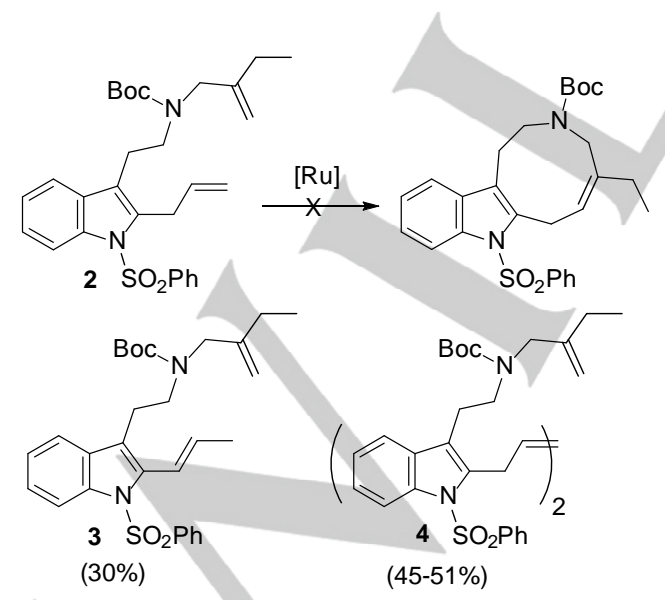

Scheme 3. Metathesis of diene 2 .
$\mathrm{Cl}_{\mathrm{PCy}}^{\mathrm{Cu}} \stackrel{\mathrm{Ph}}{\mathrm{PC} y_{3}}$

G1

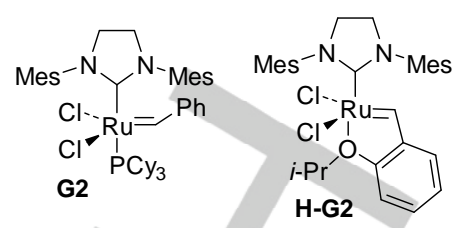

Figure 2. Ru catalysts used in this work.

Considering that in previous studies we had already encountered difficulties in assembling azonino[5,4-b]indoles with a trisubstituted double bond functionality using an RCM of dienes, ${ }^{[12]}$ at this point we decided to explore RCEYM reactions instead. The RCEYM is a derivative process of the RCM reaction, consisting of the transition-metal catalyzed skeletal reorganization of one alkene and one alkyne fragment leading to the formation of a cyclic conjugated 1,3-diene. ${ }^{[18]}$ The scope of this powerful and atom-economical transformation has been significantly expanded in recent years to include a host of new applications for the synthesis of cyclic dienes. However, despite its enormous potential, the RCEYM has been scarcely applied to the synthesis of medium-sized rings ${ }^{[19,20]}$ and only isolated examples of nine-membered-ring formation have been reported so arr. $^{[21]}$

To explore the feasibility of assembling the azonino[5,4- $b]$ indole system by means of RCEYM reactions, enyne $\mathbf{5}$ was first examined for its ring closure behavior. Enyne $\mathbf{5}$ was prepared by alkylation of propargylamine with tosylate $\mathbf{1}$, and protection of the resulting secondary amine with a Boc group (Scheme 4). Disappointingly, only extensive decomposition of the substrate was observed when $\mathbf{5}$ was submitted to the usual RCEYM conditions using ruthenium catalysts $\mathbf{G 1}$ and $\mathbf{G} 2$ in either $\mathrm{CH}_{2} \mathrm{Cl}_{2}$ or toluene.

In light of these results, we decided to prepare enyne 6, which has a $p$-nitrosulfonyl substituent (Nosyl, Ns) at the amine nitrogen, hoping that the more robust protecting group would hamper the extensive decomposition and that the conformational constraint it induces would facilitate the metathetic ring closure. Thus, enyne 6 was prepared from tosylate 1 by reaction with propargylamine, followed by protection with $p$-nitrosulfonyl chloride (Scheme 4).

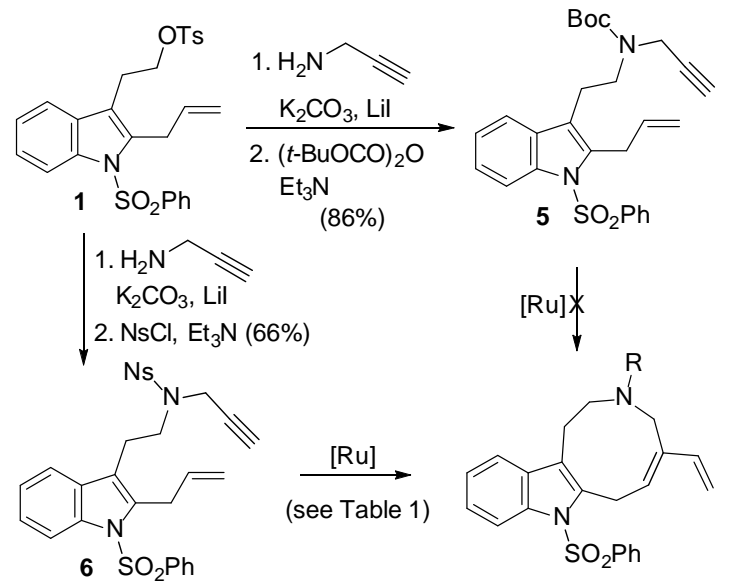


Scheme 4. Synthesis of enynes 5 and $\mathbf{6}$ and metathesis reactions.

The most representative results of the RCEYM reactions of enyne $\mathbf{6}$ are summarized in Table 1 . When 6 was subjected to standard RCEYM conditions, involving the use of either the firstgeneration Grubbs catalyst G1 (Table 1, entry 1) or the secondgeneration Grubbs catalyst G2 (Table 1, entry 2), mainly unchanged material was recovered, although small amounts of azoninoindoles $\mathbf{7 Z}, \mathbf{7 E}$, and $\mathbf{8}$ were also observed in the reaction mixtures. No significant progression was obtained by extending the reaction times.

Table 1. RCEYM reactions of enyne $6^{[\mathrm{a}]}$

\begin{tabular}{|c|c|c|c|c|c|}
\hline 6 & $\begin{array}{l}N^{N}=-H \\
=\stackrel{[R u]}{\longrightarrow} \\
={ }_{2} P h\end{array}$ & $\overbrace{7}^{N s}$ & & $N^{N s}$ & $9 \mathrm{SO}_{2} \mathrm{Ph}$ \\
\hline Entry & $\begin{array}{l}{[\mathrm{Ru}]} \\
(\mathrm{mol} \%)\end{array}$ & $\mathrm{T}$ & $t[\mathrm{~h}]$ & ${ }^{1} \mathrm{H}$ NMR ratio & $\begin{array}{l}\text { Products (yield } \\
[\%])^{[b]}\end{array}$ \\
\hline 1 & G1 (15) & reflux & 23 & $\begin{array}{l}6: 7 Z: 7 E: 8 \\
(6: 1: 1: 1)\end{array}$ & --- \\
\hline 2 & G2 (9.5) & r.t. & 6 & $\begin{array}{l}6: 7 Z: 7 E: 8 \\
(8: 1: 1: 1)\end{array}$ & --- \\
\hline 3 & G2 (22.5) & r.t. & 21 & $\begin{array}{l}7 Z: 7 E: 8: 9 \\
(1: 1: 1.5: 0.5)\end{array}$ & --- \\
\hline 4 & G2 (50) & r.t. & 3 & $\begin{array}{l}7 Z: 7 E: 8: 9 \\
(1: 1: 2: 0.6)\end{array}$ & $\begin{array}{l}\text { 7Z:7E:8 } \\
(1: 1: 4,35 \%) \\
9(24 \%)\end{array}$ \\
\hline 5 & G2 (17.5) & reflux & 30 & $\begin{array}{l}7 Z: 7 E: 8: 9 \\
(1: 1: 1: 0.5)\end{array}$ & $\begin{array}{l}7 E(9 \%) \\
7 Z: 8(1: 1,20 \%) \\
9(16 \%)\end{array}$ \\
\hline 6 & $\begin{array}{l}\text { H-G2 } \\
(12.5)\end{array}$ & reflux & 24 & $\begin{array}{l}\text { 7Z:7E:8 } 8^{[c]}: 9 \\
(1: 1: 1: 0.5)\end{array}$ & --- \\
\hline
\end{tabular}

[a] All reactions were performed using a $0.001 \mathrm{M}$ solution of 6 in $\mathrm{CH}_{2} \mathrm{Cl}_{2}$ under an $\mathrm{Ar}$ atmosphere. [b] Isolated yields. [c] 8' is the analog of 8 with an o- $(i-$ $\mathrm{PrO}) \mathrm{C}_{6} \mathrm{H}_{4}$ group instead of $\mathrm{Ph}$.

In contrast, the starting material was completely consumed when the reaction was run in the presence of a higher amount of G2 $(22.5 \mathrm{~mol} \%)$ in $\mathrm{CH}_{2} \mathrm{Cl}_{2}$ at room temperature (Table 1, entry 3 ). Under these conditions, a 1:1:1.5:0.5 mixture of azoninoindoles $7 Z, 7 E, 8$, and 9 was obtained, all of which were derived from the exo-mode ring closure pathway. Interestingly, while 7 was obtained as a $1: 1$ mixture of $Z$ and $E$ isomers on the endocyclic double bond, ${ }^{[22]}$ only the Z-stereochemistry was observed for 8 and 9, both of which are products of an apparent overreaction of the desired cyclization product $\mathbf{7}$. While 8 incorporates a benzylidene substituent proceeding from the precatalyst $\mathbf{G 2}$ on the exocyclic double bond, 9 is the product of metathetic dimerization of 7 .
Increasing the amount of the catalyst G2 still further enhanced the formation of 8 (Table 1, entry 4). Under these reaction conditions, 7Z, 7E, 8, and $\mathbf{9}$ were obtained as a 1:1:2:0.6 mixture in a combined $59 \%$ overall yield. A better ratio of the desired azoninoindoles 7Z-7E to the overreaction products 8-9 was obtained when using a smaller amount of the catalyst G2 in $\mathrm{CH}_{2} \mathrm{Cl}_{2}$ at reflux (Table 1, entry 5). However, after flash chromatography, the cyclization products were isolated in a lower overall yield. The use of the second-generation HoveydaGrubbs catalyst H-G2 afforded a similar result (Table 1, entry 6). The results summarized in Table 1 suggest that a loss of catalyst metathesis activity occurs during the reactions of enyne 6, which provide only partial conversion. In consequence, larger amounts of catalyst are required, leading to the formation of the side products $\mathbf{8}$ and $\mathbf{9}$. Experimental and computational studies on the effect of the enyne substituents in RCEYM processes have shown that some competitive non-productive pathways, leading to catalyst deactivation, can take place when the reacting compound is a terminal alkyne. ${ }^{[23]}$

The beneficial effect of ethylene in the RCEYM reactions of terminal alkynes for the formation of up to 8-membered rings was revealed by the pioneering work of Mori, ${ }^{[24]}$ although the exact nature of this effect is not completely understood. ${ }^{[25]}$ Nevertheless, we suspected that the use of ethylene for the formation of the 9-membered ring of the azonino[5,4-b]indole would promote the competitive cross diene metathesis, as occurs in macrocyclization reactions via RCEYM. ${ }^{[26]}$ Indeed, treatment of enyne 6 with catalyst G2 under an ethylene atmosphere at room temperature produced the cross metathesis product $\mathbf{1 0}$ in good yield (Scheme 5). Subsequent RCM of this substrate with $\mathbf{G} 2$ in refluxing $\mathrm{CH}_{2} \mathrm{Cl}_{2}$ selectively yielded the azecino[5,4-b]indole 11, which otherwise would be the endoproduct of the RCEYM of $\mathbf{6}$. It should be noted that this product was never observed in the RCEYM reaction mixtures of $\mathbf{6}$ (Table 1), which confirms that the RCEYM selectively follows the exomode ring closure. These results fully agree with the well established ring size-dependent exo/endo selectivity in the RCEYM, according to which the formation of common and medium-sized rings generally follows the exo-mode ring closure path. ${ }^{[26,27]}$

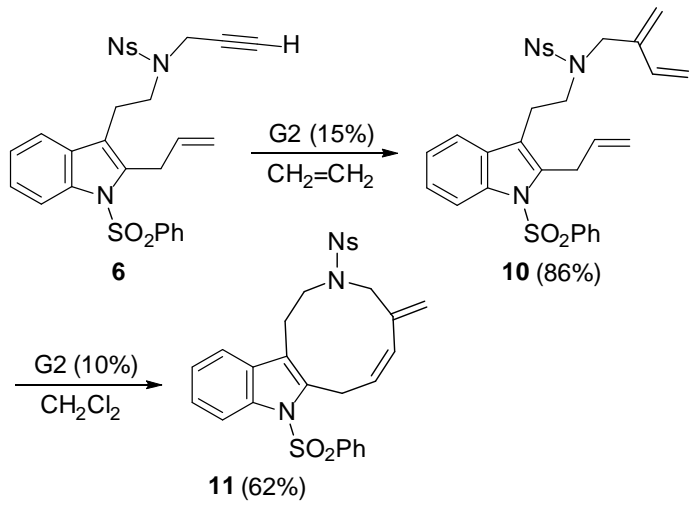

Scheme 5. Metathesis of enyne 6 in the presence of ethylene and synthesis of the endo-product 11. 
As the use of internal alkynes avoids at least part of the nonproductive pathways that occur during the RCEYM reactions leading to medium-sized rings, we decided to explore the metathetic behavior of enynes 12 and 13a-b, which bear a substituted alkyne moiety. Enynes 12 and 13a-b were prepared by reaction of tosylate $\mathbf{1}$ with 3 -(trimethylsilyl)-2-propynamine ${ }^{[28]}$ or 2-butynamine, respectively, followed by protection of the resulting secondary amines as the corresponding sulfonamides (Scheme 6).

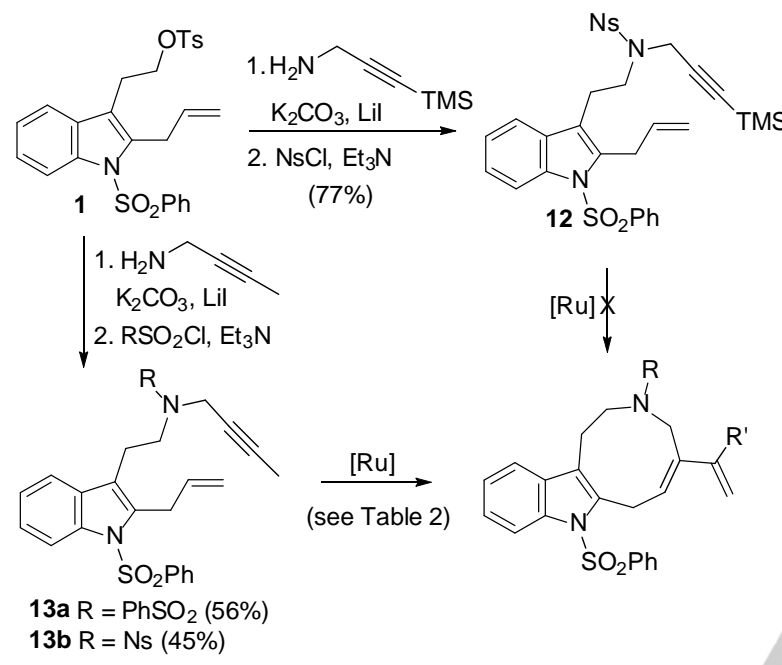

Scheme 6. Synthesis of enynes 12 and 13a-b, and metathesis reactions.
When 12 was subjected to standard RCM conditions, involving the use of either $\mathbf{G 1}$, G2 or $\mathbf{H}-\mathbf{G 2}$, unchanged material was mainly recovered and only small amounts of the corresponding double-bond isomerization product were observed. The low tendency of enyne $\mathbf{1 2}$ to undergo RCEYM is probably due to the steric hindrance generated by the bulky TMS group, which hampers the coordination of the alkyne to the ruthenium catalyst required for the metathesis.

We next focused on the reactivity of enynes $13 a$ and $13 b$ under RCEYM conditions, hoping that the less bulky methyl group would facilitate the cyclization. The results of these reactions are summarized in Table 2.

Enyne 13a was less reactive than 6 in the RCEYM reaction and was recovered unchanged when treated with the catalyst $\mathbf{G 1}$ in $\mathrm{CH}_{2} \mathrm{Cl}_{2}$ at reflux (Table 2, entry 1 ). Even under forcing conditions, only the starting material was recovered (Table 2, entry 2). The use of $\mathrm{G} 2$ in refluxing $\mathrm{CH}_{2} \mathrm{Cl}_{2}$ afforded a mixture of the starting material and azoninoindoles 14a and 15a (Table 2, entry 3). Changing the solvent to toluene (Table 2, entry 4) or using the catalyst H-G2 instead of G2 (Table 2, entry 5) resulted in a slower transformation. More satisfactorily, the material was completely converted when using a higher amount of G2, which resulted in the formation of a 3:1 mixture of $14 a$ and $15 a$ (Table 2 , entry 6 ). Enyne 13b, which possesses a $p$-nitrosulfonyl group at the nitrogen atom, showed a similar behavior (Table 2, entry 7). Remarkably, only the Z-stereochemistry was observed for the endocyclic double bond of $14 a-b$ and $15 a-b$, which sharply contrasts with the formation of the $Z$ - and $E$-isomers in the RCEYM reactions of 6 .

Table 2. RCEYM reactions of enynes $13 a-b .^{[a]}$

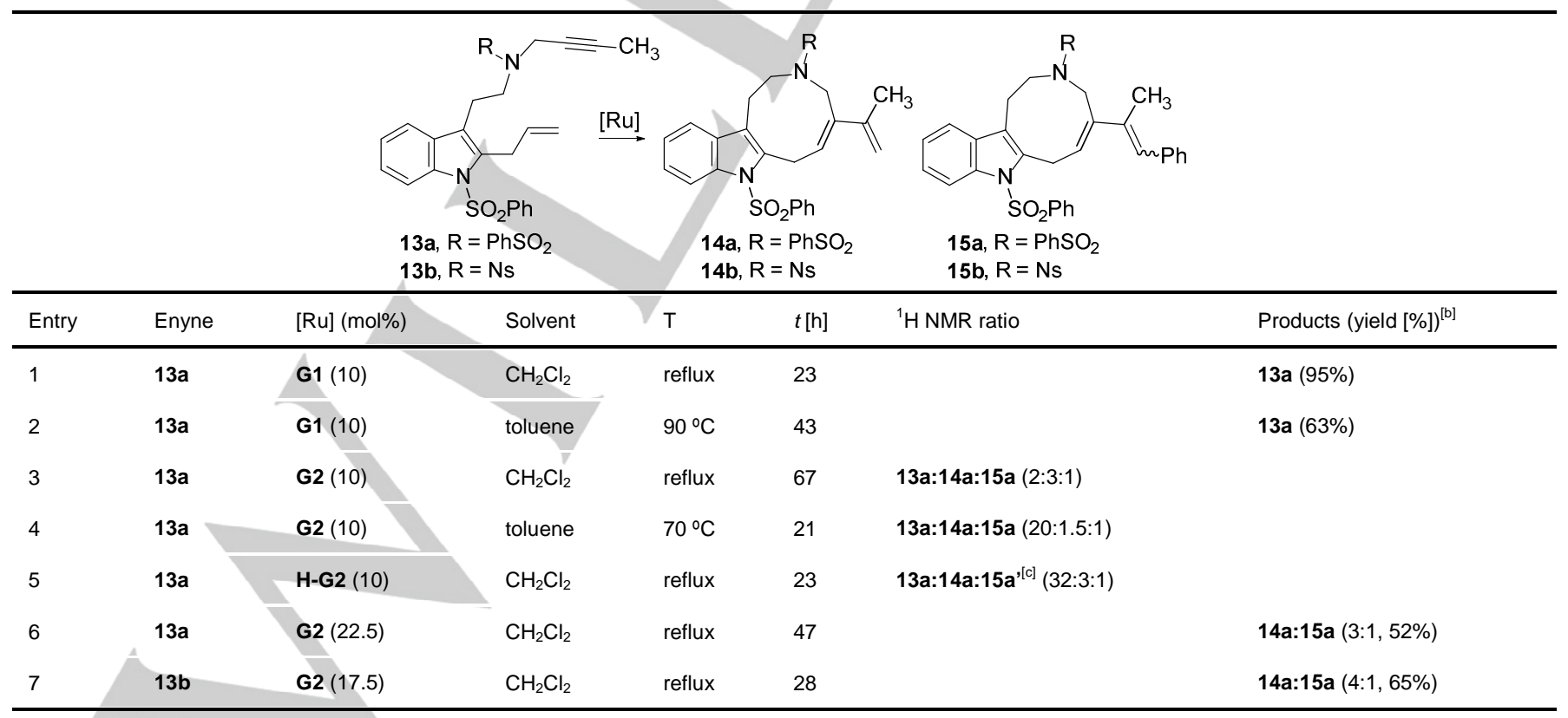

[a] All reactions were performed using a $0.001 \mathrm{M}$ solution of the enyne in the indicated solvent under an Ar atmosphere. [b] Isolated yields. [c] $15^{\prime}$ is the analog of 
15 with an $o-(i-\mathrm{PrO}) \mathrm{C}_{6} \mathrm{H}_{4}$ group instead of $\mathrm{Ph}$.

As shown in Table 2, and in agreement with the literature, the internal alkynes 13a-b afforded much higher ring closing efficiency than the terminal alkyne 6 . From these results we can also conclude that an efficient catalytic cycle is established during the RCEYM of internal enynes 13a-b.

At this point we decided to explore the use of alkynyl halides in the RCEYM to form the azonino[5,4-b]indole system A (Scheme 1). Although this usage is unprecedented, we wondered if the application of alkynyl halides ${ }^{[29]}$ in these reactions could benefit from the advantages of internal alkynes while affording a halo1,3-diene, which would allow further synthetic transformations by transition metal-catalyzed coupling reactions.

To test the use of alkynyl halides in the RCEYM, we chose enynes 17- $\mathbf{B r}, \mathbf{1 7}-\mathbf{I}$ and $\mathbf{1 7}-\mathbf{C l}$, which were easily prepared in $71 \%, 73 \%$ and $50 \%$ overall yields, respectively, by alkylation of propargylamine with tosylate $\mathbf{1}$, followed by protection of the resulting secondary amine with a tosyl group, and halogenation of the terminal alkyne of $\mathbf{1 6}$ by reaction with the corresponding $\mathrm{N}$-halosuccinimides (Scheme 7).

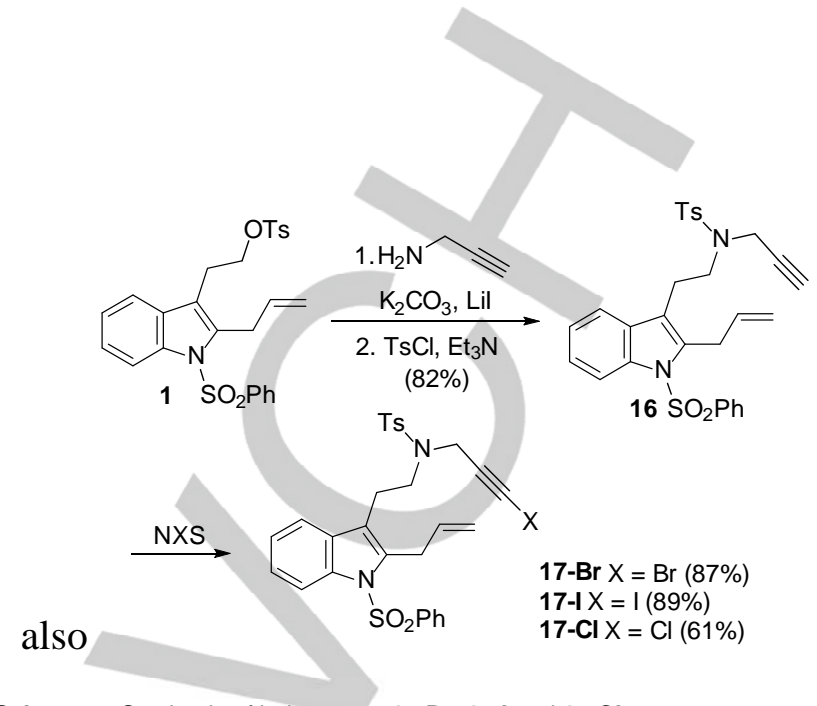

Scheme 7. Synthesis of haloenynes $17-\mathrm{Br}, 17-\mathrm{I}$ and $17-\mathrm{CI}$.

With haloenines 17- $\mathrm{Br}, \mathbf{1 7}-\mathrm{I}$ and $17-\mathrm{Cl}$ in hand, we focused on their RCEYM reactions (Table 3 ).

Table 3. RCEYM reactions of enynes 17-Br, 17-I, and 17-Cl. ${ }^{[a]}$

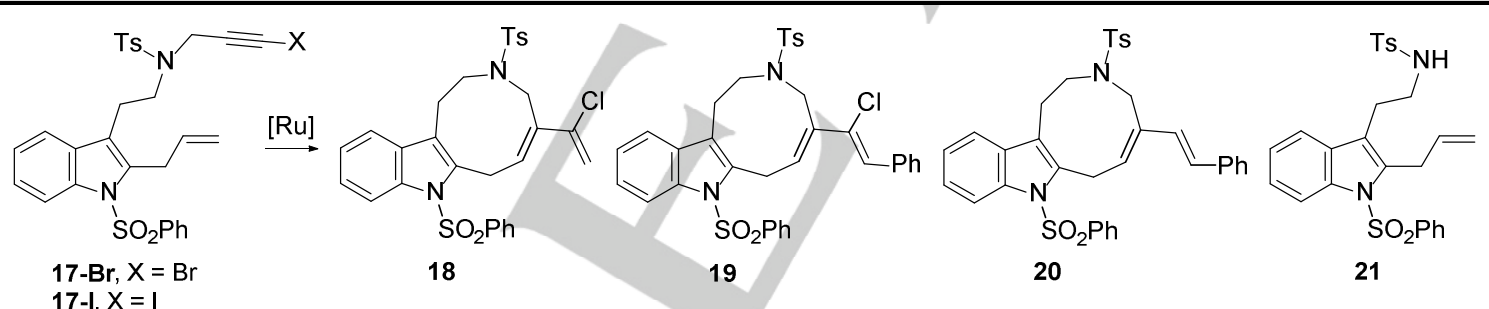

17-Cl $\mathrm{X}=\mathrm{Cl}$

\begin{tabular}{|c|c|c|c|c|c|c|c|}
\hline Entry & Enyne & {$[\mathrm{Ru}](\mathrm{mol} \%)$} & Solvent & $\mathrm{T}$ & $t[\mathrm{~h}]$ & ${ }^{1} \mathrm{H}$ NMR ratio & Products $(\text { yield }[\%])^{[b]}$ \\
\hline 1 & $17-\mathrm{Br}$ & G1 (25) & $\mathrm{CH}_{2} \mathrm{Cl}_{2}$ & reflux & 24 & & $17-\mathrm{Br}$ \\
\hline 2 & $17-\mathrm{Br}$ & G2 (15) & $\mathrm{CH}_{2} \mathrm{Cl}_{2}$ & reflux & 48 & 17-Br:19:21 (10:1:1) & \\
\hline 3 & $17-\mathrm{Br}$ & G2 (35) & $\mathrm{CH}_{2} \mathrm{Cl}_{2}$ & reflux & 71 & 18:19:20:21 (1:14:2:2) & $\begin{array}{l}\text { 18:19:20 (1:14:2, 35\%) } \\
21(5 \%)\end{array}$ \\
\hline 4 & 17-Br & G2 (20) & toluene & $90 \stackrel{\circ}{\circ}$ & 29 & & $-{ }_{--}^{[c]}$ \\
\hline 5 & $17-\mathrm{Br}$ & H-G2 (15) & $\mathrm{CH}_{2} \mathrm{Cl}_{2}$ & reflux & 24 & & $17-\mathrm{Br}$ \\
\hline 6 & $17-\mathrm{Br}$ & G2 (50) & $\mathrm{CH}_{2} \mathrm{Cl}_{2}$ & $47^{\circ} \mathrm{C}^{[\mathrm{d}]}$ & 54 & & $21(30 \%)$ \\
\hline 7 & $17-I$ & G2 (35) & $\mathrm{CH}_{2} \mathrm{Cl}_{2}$ & reflux & 68 & 19:20:21 (10:2:1) & $\begin{array}{l}19: 20(5: 1,35 \%) \\
21(6 \%)\end{array}$ \\
\hline 8 & $17-\mathrm{Cl}$ & G2 (35) & $\mathrm{CH}_{2} \mathrm{Cl}_{2}$ & reflux & 72 & 17-CI:18:19:21 (10:1:10:5.5) & $\begin{array}{l}\text { 17-Cl }(21 \%) \\
18: 19(1: 10,22 \%) \\
21(10 \%)\end{array}$ \\
\hline
\end{tabular}

[a] All reactions were performed using a $0.001 \mathrm{M}$ solution of the enyne in the indicated solvent, under an Ar atmosphere. [b] Isolated yields. [c] Decomposition, trace amounts of $\mathbf{2 1}$ were observed in the reaction mixture. [d] Bath temperature. The reaction was performed under an ethylene atmosphere in a sealed tube. 
When 17- $\mathrm{Br}$ was treated with the catalyst $\mathrm{G} 1$ in refluxing $\mathrm{CH}_{2} \mathrm{Cl}_{2}$, the unchanged starting material was recovered (Table 3 , entry 1). Changing the catalyst to $\mathbf{G} 2$ resulted in the formation of small amounts of the dealkylation compound $21^{[30]}$ and what seemed to be an azonino[5,4-b]indole (Table 3 , entry 2). The use of higher amounts of catalyst promoted the complete consumption of the material to give a reaction mixture in which the azonino[5,4- $b]$ indole 19 was the major product, although small amounts of the desired cyclization product 18, the hydrodehalogenation byproduct $\mathbf{2 0}$, and amine 21 were also observed (Table 3, entry 3). After flash chromatography, the three cyclization products were isolated in a modest $35 \%$ overall yield. It should be noted that both 18 and 19 bear a $\mathrm{Cl}$ substituent instead of the original $\mathrm{Br}^{\left[{ }^{[1]}\right.}$ Interestingly, only the $Z$ stereochemistry was observed for the endocyclic double bond of the cyclization products $\mathbf{1 8}, \mathbf{1 9}$ and $\mathbf{2 0}$.

Changing the solvent to toluene promoted the decomposition of the material (Table 3, entry 4) and using the catalyst H-G2 instead of G2 resulted in no reaction (Table 3, entry 5). On the other hand, treatment of enyne 17-Br with G2 under an ethylene atmosphere afforded a complex mixture from which $\mathbf{2 1}$ was isolated in $30 \%$ yield (Table 3 , entry 6 ).

The use of the reaction conditions of entry 3 with alkynyl iodide 17-I also afforded 19 as the major reaction product, together with minor amounts of $\mathbf{2 0}$ and $\mathbf{2 1}$ (Table 3, entry 7). Once again, during the metathetic ring closure the iodo substituent was exchanged for $\mathrm{Cl}$. Finally, when the same reaction conditions were used with alkynyl chloride $17-\mathrm{Cl}$, although 19 was still the major reaction product, the reaction was comparatively slower and no hydrodehalogenation product was obtained (Table 3 , entry 8).

As can be seen in Table 3, the haloenynes 17- Br, 17-I and 17$\mathrm{Cl}$ resemble the terminal enyne 6 in their metathetic behavior, with a similar deactivation of the catalyst during the RCEYM process. Consequently, larger amounts of catalyst are required to achieve the complete conversion of the starting material.

In enyne metathesis, the mechanism at play is still a matter of debate. The question asked is whether an "ene-then-yne" or an "yne-then-ene" pathway is involved. ${ }^{[18]}$ Although most of the experimental data suggest that the "ene-then-yne" mechanism is the most probable when using a Ru-based catalyst, ${ }^{[25,32]}$ experiments presenting evidence in favor of the "yne-then-ene" also exist. ${ }^{[30,33]}$

The "ene-then-yne" and "yne-then-ene" pathways with the enyne substrates (B) studied in our work are shown in Schemes 8 and 9 , respectively.

According to the "ene-then-yne" pathway, intermediate $\mathbf{C}$ would first be formed and a metathesis cyclization would lead to intermediate cat. A (Scheme 8). This ruthenium carbene would be the species that reacts with another molecule of enyne $\mathbf{B}$ through the propagation cycle to give the final product $\mathbf{A}$. As the amount of enyne $\mathbf{B}$ in the reaction mixture is reduced during the RCEYM, cat. A would undergo competitive metathetic reactions with vinylbenzene or the cyclization product $\mathbf{A}$ to give, respectively, D or the dimerization product $\mathbf{E}$. In consequence, both compounds would actually be overreaction products.

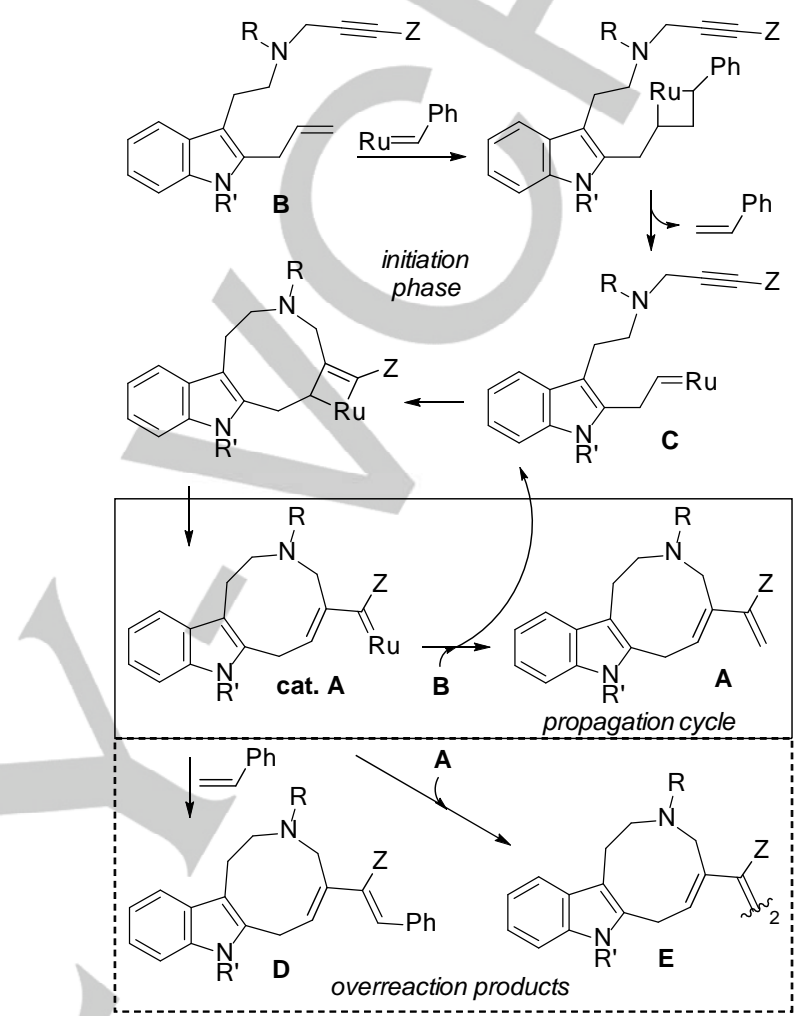

Scheme 8. "Ene-then-yne" pathway with enynes B.

On the other hand, following the "yne-then-ene" pathway, intermediate $\mathbf{F}$ would be generated first (Scheme 9). A subsequent metathesis cyclization would lead to $\mathbf{D}$, which should be considered as a reaction byproduct rather than an overreaction product, as well as methylenruthenium, which would be the catalytic species in the propagation cycle of the "yne-then-ene" pathway. Dimer E would be formed by cross metathesis overreaction of $\mathbf{A}$.

Looking at both reaction mechanisms, it is clear that although both pathways provide the same end product $(\mathbf{A})$, the intermediates are very different. Considering the complete initiation of the metathesis catalyst, the most striking difference is that in the "yne-then-ene" pathway, $x$ mol\% of precatalyst would give rise to $x \mathrm{~mol} \%$ of $\mathbf{D}$, which bears the benzylidene substituent. In contrast, in the "ene-then-yne" pathway, $x$ mol\% of vinylbenzene should be obtained. 


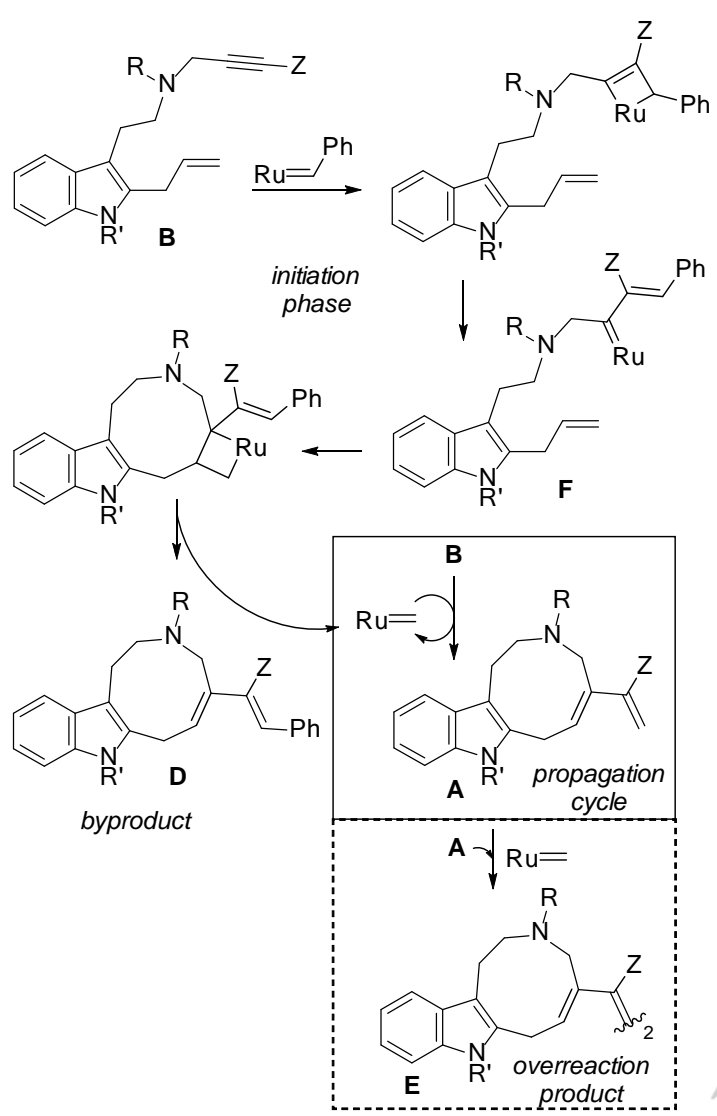

Scheme 9. "Yne-then-ene" pathway with enynes B

Although all the products obtained in the RCEYM of enynes 6 , 13a-b, and 17-X could be a result of either pathway, in our opinion the results of these reactions could be more easily explained by the "yne-then-ene" mechanism. Thus, the ${ }^{1} \mathrm{H}$ NMR analysis of the RCEYM reaction mixtures of terminal alkyne 6 (Table 1) in which low conversion was observed, showed that 8 (D in Scheme 9) was present in about $11 \%$ (entry 1, Table 1) and $9 \%$ (entry 2, Table 1). These percentages are only slightly lower than the amount of precatalyst used in each case. Moreover, the formation of the side product vinylbenzene was not detected in these reaction mixtures.

The same situation was observed in the RCEYM reactions of haloenynes $17-\mathbf{X}$. Thus, in the reaction of $17-\mathbf{B r}$ using $35 \%$ of G2 (entry 3, Table 3), 19 and $\mathbf{2 0}$ were obtained in 33\% overall yield. Similarly, the RECYM of 17-I in the presence of $35 \%$ of G2 (entry 7, Table 3) gave 19 and 20 in a combined $35 \%$ yield.

Although the situation is less clear in the RCEYM reactions of enynes 13a-b and the coexistence of both pathways cannot be completely ruled out, we believe that the "yne-then-ene" pathway is still the most likely considering the amount of side products 15a-b isolated (see entries 6 and 7, Table 2).

Another point at issue of the present RCEYM reactions is why the terminal alkyne $\mathbf{6}$ gives the cyclization product $\mathbf{7}$ as a mixture of $Z$ and $E$ isomers, while only the $Z$-stereochemistry is observed in the side products $\mathbf{8}$ and $\mathbf{9}$, as well as in all the cyclization products of alkynes 13a-b and haloenynes 17-X. Although other explanations cannot be excluded, ${ }^{[34]}$ we think that the ZIE mixture may be due to a secondary metathetical isomerization ${ }^{[26,35]}$ of the initially formed $Z$-stereoisomer.

\section{Conclusions}

We have explored the use of the ring-closing enyne metathesis in the synthesis of azonino[5,4-b]indoles embodying a $\mathrm{C}_{5}-\mathrm{C}_{6}$ double bond and an all carbon chain at $\mathrm{C}_{5}$. Whereas RCEYM of internal alkynes provided an effective route to the azoninoindole nucleus, both terminal alkynes and alkynyl halides failed to establish an efficient catalytic cycle. On the basis of the experimental results, the most likely explanation for the outcome of these RCEYM processes is the "yne-then-ene" mechanism. The RCEYM reactions of alkynyl halides described in this work constitute the first reported study on metathesis cyclizations with this type of alkynes. Further exploration of the use of alkynyl halides in RCEYM reactions for the synthesis of common and medium-sized nitrogen heterocycles, as well as to gain insight into the reaction mechanism, is underway in our laboratory and will be reported in due course.

\section{Experimental Section}

General Methods. All commercially available reagents were used without further purification. All nonaqueous reactions were carried out under an argon atmosphere. Reaction courses and product mixtures were routinely monitored by TLC on $\mathrm{SiO}_{2}$ (silica gel $60 \mathrm{~F}_{254}$ ), and the spots were located with UV light or $1 \%$ aqueous $\mathrm{KMnO}_{4}$ solution. Drying of organic extracts during workup of reactions was performed over anhydrous $\mathrm{Na}_{2} \mathrm{SO}_{4}$. The solvents were evaporated under reduced pressure with a rotatory evaporator. Flash chromatography was carried out on $\mathrm{SiO}_{2}$ (silica gel 60, SDS, 0.04-0.06 mm). ${ }^{1} \mathrm{H}$ - and ${ }^{13} \mathrm{C}$ NMR spectra were recorded in $\mathrm{CDCl}_{3}$ using $\mathrm{Me}_{4} \mathrm{Si}$ as the internal standard, with a Varian Gemini 300 or a Varian Mercury 400 instrument. Chemical shifts are reported in ppm downfield $(\delta)$ from $\mathrm{Me}_{4} \mathrm{Si}$ for ${ }^{1} \mathrm{H}$ - and ${ }^{13} \mathrm{C} \mathrm{NMR}$. HRMS were obtained using a LC/MSD TOF mass spectrometer.

\section{Synthesis of diene 2}

2-Allyl-3-[2-\{N-(2-ethylallyl)-N-(tert-butoxycarbonyl)amino\}ethyl]-1(phenylsulfonyl)indole (2). A mixture of tosylate $1^{[9 \mathrm{c}]}(0.68 \mathrm{~g}, 1.38 \mathrm{mmol})$, 2-ethylallylamine hydrochloride ${ }^{[15]}(1.5 \mathrm{~g}, 8.28 \mathrm{mmol}), \mathrm{K}_{2} \mathrm{CO}_{3}(1.52 \mathrm{~g}$, $11.04 \mathrm{mmol})$, and a catalytic amount of $\mathrm{Lil}$ in $\mathrm{CH}_{3} \mathrm{CN}(30 \mathrm{~mL})$ was stirred at $85^{\circ} \mathrm{C}$ for $24 \mathrm{~h}$ in a sealed tube. The solvent was evaporated and the resulting residue was diluted with $\mathrm{CH}_{2} \mathrm{Cl}_{2}$ and washed with a saturated aqueous $\mathrm{Na}_{2} \mathrm{CO}_{3}$ solution. The organic layer was dried, filtered, and concentrated to give the crude secondary amine, which was directly used in the next step. A solution of the secondary amine, $\mathrm{Et}_{3} \mathrm{~N}(0.7 \mathrm{~mL}, 5.0$ $\mathrm{mmol})$, and $(t-\mathrm{BuOCO})_{2} \mathrm{O}(0.51 \mathrm{~g}, 2.34 \mathrm{mmol})$ in $\mathrm{MeOH}(30 \mathrm{~mL})$ was heated at reflux overnight. The solvent was evaporated and the residue was diluted with $\mathrm{CH}_{2} \mathrm{Cl}_{2}$ and washed with $2 \mathrm{~N} \mathrm{HCl}$ and brine. The organic extracts were dried, filtered, and concentrated to give the crude product. After chromatography (from hexanes to 8:2 hexanes/EtOAc) diene 2 was obtained as a pale yellow oil: $0.25 \mathrm{~g}(35 \%) ;{ }^{1} \mathrm{H}$ NMR $(300 \mathrm{MHz}$, mixture of rotamers) $\delta 0.98$ (broad q, $J=6.9 \mathrm{~Hz}, 3 \mathrm{H}), 1.46$ and $1.49(2 \mathrm{~s}, 9 \mathrm{H})$, $1.90(\mathrm{~m}, 2 \mathrm{H}), 2.82(\mathrm{~m}, 2 \mathrm{H}), 3.24(\mathrm{~m}, 2 \mathrm{H}), 3.47$ and $3.69(2 \mathrm{~s}, 2 \mathrm{H}), 3.80$ 
(dt, $J=6.0$ and $1.5 \mathrm{~Hz}, 2 \mathrm{H}$ ), 4.61, 4.69, 4.77 and 4.82 (4 broad signals, 2H), 5.01 and $5.04(2 \mathrm{~s}, 2 \mathrm{H}), 5.98(\mathrm{~m}, 1 \mathrm{H}), 7.25(\mathrm{~m}, 2 \mathrm{H}), 7.36(\mathrm{t}, J=7.5$ $\mathrm{Hz}, 2 \mathrm{H}), 7.48(\mathrm{~m}, 2 \mathrm{H}), 7.72(\mathrm{~d}, J=7.5 \mathrm{~Hz}, 2 \mathrm{H}), 8.18(\mathrm{~d}, J=8.7 \mathrm{~Hz}, 1 \mathrm{H})$; ${ }^{13} \mathrm{C}$ NMR (100.6 MHz, mixture of rotamers) $\delta 12.0$ and $12.2\left(\mathrm{CH}_{3}\right), 22.8$ and $23.4\left(\mathrm{CH}_{2}\right), 26.0\left(\mathrm{CH}_{2}\right), 28.4$ and $28.5\left(3 \mathrm{CH}_{3}\right), 30.0$ and $30.1\left(\mathrm{CH}_{2}\right)$, 45.8 and $46.1\left(\mathrm{CH}_{2}\right), 51.7$ and $52.6\left(\mathrm{CH}_{2}\right), 79.5$ and $79.8(\mathrm{C}), 109.8$ and $109.9\left(\mathrm{CH}_{2}\right), 115.0$ and $115.1(\mathrm{CH}), 116.1\left(\mathrm{CH}_{2}\right), 118.4$ and $118.8(\mathrm{CH})$, 119.2 and $119.6(\mathrm{C}), 123.5$ and $123.6(\mathrm{CH}), 124.4(\mathrm{CH}), 126.3(2 \mathrm{CH})$, $129.1(2 \mathrm{CH}), 130.3$ and $130.5(\mathrm{C}), 133.5(\mathrm{CH}), 135.2$ and $135.4(\mathrm{CH})$, 135.3 (C), 136.6 (C), 139.9 (C), 147.1 and 147.2 (C), 155.3 and 155.5 (C); ESI-HRMS calcd for $\mathrm{C}_{29} \mathrm{H}_{36} \mathrm{~N}_{2} \mathrm{NaO}_{4} \mathrm{~S}$ : $531.2288[\mathrm{M}+\mathrm{Na}]^{+}$, found: 531.2295 .

\section{Characterization data for diene 3 and dimeric compound 4}

3-[2-\{N-(2-ethylallyl)-N-(tert-butoxycarbonyl)amino\}ethyl]-1(phenylsulfonyl)-2-(propen-1-yl)indole (3). Elution with 8:2 hexanes/EtOAc; Yellow oil: ${ }^{1} \mathrm{H}$ NMR $(400 \mathrm{MHz}$, mixture of rotamers) $\delta$ 0.97 (broad m, 3H), $1.44(\mathrm{~s}, 9 \mathrm{H}), 1.87(\mathrm{~m}, 2 \mathrm{H}), 1.98(\mathrm{dd}, J=6.4$ and 1.6 $\mathrm{Hz}, 3 \mathrm{H}$ ), 2.87 (broad signal, $2 \mathrm{H}$ ), 3.28 (broad signal, $2 \mathrm{H}$ ), 3.47 and 3.67 (2 broad signals, $2 \mathrm{H}$ ), 4.57, 4.63, 4.76 and 4.80 (4 broad signals, $2 \mathrm{H}$ ), 5.75 and $5.80(2 \mathrm{~m}, 1 \mathrm{H}), 6.72(\mathrm{dd}, J=14.0$ and $1.6 \mathrm{~Hz}, 1 \mathrm{H}), 7.21-7.35(\mathrm{~m}$ $4 \mathrm{H}), 7.45(\mathrm{~m}, 2 \mathrm{H}), 7.69$ and $7.73(2 \mathrm{~d}, J=7.6 \mathrm{~Hz}, 2 \mathrm{H}), 8.20(\mathrm{~d}, J=7.6 \mathrm{~Hz}$ $1 \mathrm{H}) ;{ }^{13} \mathrm{C}$ NMR $\left(100.6 \mathrm{MHz}\right.$, mixture of rotamers) $\delta 12.0$ and $12.2\left(\mathrm{CH}_{3}\right)$, $18.9\left(\mathrm{CH}_{3}\right), 23.5$ and $23.9\left(\mathrm{CH}_{2}\right), 26.0\left(\mathrm{CH}_{2}\right), 28.4\left(3 \mathrm{CH}_{3}\right), 45.7$ and 46.1 $\left(\mathrm{CH}_{2}\right), 51.2$ and $52.2\left(\mathrm{CH}_{2}\right), 79.5$ and $79.7(\mathrm{C}), 109.8\left(\mathrm{CH}_{2}\right), 115.2(\mathrm{CH})$, 118.9 and $119.3(\mathrm{CH}), 119.5(\mathrm{C}), 121.1 .5$ and $121.5(\mathrm{CH}), 123.6$ and $123.8(\mathrm{CH}), 124.8(\mathrm{CH}), 126.7(2 \mathrm{CH}), 128.8(2 \mathrm{CH}), 131.2$ and $131.5(\mathrm{C})$, 132.2 and $132.4(\mathrm{CH}), 133.5(\mathrm{CH}), 135.7(\mathrm{C}), 136.1(\mathrm{C}), 138.6(\mathrm{C}), 147.1$ and 147.3 (C), 155.5 (C); ESI-HRMS calcd for $\mathrm{C}_{29} \mathrm{H}_{36} \mathrm{~N}_{2} \mathrm{NaO}_{4} \mathrm{~S}: 531.2288$ $[\mathrm{M}+\mathrm{Na}]^{+}$, found: 531.2292 .

Dimer 4. Elution with 8:2 hexanes/EtOAc; Yellow oil: ${ }^{1} \mathrm{H}$ NMR $(400 \mathrm{MHz}$, mixture of rotamers) $\delta 0.96(\mathrm{t}, J=7.6 \mathrm{~Hz}, 3 \mathrm{H}), 1.44(\mathrm{~s}, 9 \mathrm{H}), 1.88$ (broad signal, $2 \mathrm{H}$ ), 2.80 (broad signal, $2 \mathrm{H}$ ), 3.20 (broad signal, $2 \mathrm{H}$ ), 3.46 and 3.63 (2 broad signals, $2 \mathrm{H}$ ), 3.69 (broad signal, $2 \mathrm{H}$ ), 4.61, 4.65, 4.74 and 4.77 (4 broad s, $2 \mathrm{H}), 5.66$ (broad signal, $2 \mathrm{H}), 7.27(\mathrm{~m}, 3 \mathrm{H}), 7.40(\mathrm{~m}, 3 \mathrm{H})$, $7.65(\mathrm{~d}, J=5.6 \mathrm{~Hz}, 2 \mathrm{H}), 8.14(\mathrm{~d}, J=8 \mathrm{~Hz}, 1 \mathrm{H}) ;{ }^{13} \mathrm{C} \mathrm{NMR}(100.6 \mathrm{MHz}$, mixture of rotamers) $\delta 12.0$ and $12.2\left(\mathrm{CH}_{3}\right), 22.7$ and $23.4\left(\mathrm{CH}_{2}\right), 26.0$ $\left(\mathrm{CH}_{2}\right), 28.4\left(3 \mathrm{CH}_{3}\right), 28.9\left(\mathrm{CH}_{2}\right), 45.9$ and $46.3\left(\mathrm{CH}_{2}\right), 51.8$ and 52.3 $\left(\mathrm{CH}_{2}\right), 79.4$ and $79.8(\mathrm{C}), 109.7\left(\mathrm{CH}_{2}\right), 115.2(\mathrm{CH}), 118.4$ and $118.9(\mathrm{CH})$ 119.0 and $119.4(\mathrm{C}), 123.6(\mathrm{CH}), 124.4(\mathrm{CH}), 126.2(2 \mathrm{CH}), 128.8(\mathrm{CH})$, $129.0(2 \mathrm{CH}), 130.4$ and $130.6(\mathrm{C}), 133.4(\mathrm{CH}), 135.6(\mathrm{C}), 136.5(\mathrm{C})$, 139.0 (C), 147.2 and 147.4 (C), 155.3 and 155.5 (C); ESI-HRMS calcd for $\mathrm{C}_{56} \mathrm{H}_{68} \mathrm{~N}_{4} \mathrm{NaO}_{8} \mathrm{~S}_{2}: 1011.4371[\mathrm{M}+\mathrm{Na}]^{+}$, found: 1011.4373 .

General procedure for the preparation of enynes $5,6,12,13 a$, and $13 \mathrm{~b}$

A mixture of tosylate $1(0.50 \mathrm{~g}, 1.01 \mathrm{mmol})$, the corresponding propargylic amine $(7.07 \mathrm{mmol}), \mathrm{K}_{2} \mathrm{CO}_{3}(0.28 \mathrm{~g}, 2.02 \mathrm{mmol})$, and a catalytic amount of Lil in $\mathrm{CH}_{3} \mathrm{CN}\left(12 \mathrm{~mL}\right.$ ) was stirred at $85^{\circ} \mathrm{C}$ for $60 \mathrm{~h}$ in a sealed tube. The solvent was evaporated and the resulting residue was diluted with $\mathrm{CH}_{2} \mathrm{Cl}_{2}$ and washed with a saturated aqueous $\mathrm{Na}_{2} \mathrm{CO}_{3}$ solution. The organic layer was dried, filtered, and concentrated to give the corresponding crude secondary amine, which was directly used in the next step.

A solution of the above amine, $\mathrm{Et}_{3} \mathrm{~N}(0.15 \mathrm{~mL}, 1.11 \mathrm{mmol})$, and di-tertbutyldicarbonate or the corresponding sulfonylchloride $(1.11 \mathrm{mmol})$ in $\mathrm{CH}_{2} \mathrm{Cl}_{2}(15 \mathrm{~mL})$ was heated at reflux overnight. The reaction mixture was diluted with $\mathrm{CH}_{2} \mathrm{Cl}_{2}(15 \mathrm{~mL})$ and washed successively with $2 \mathrm{~N} \mathrm{HCl}(3 \times$ $25 \mathrm{~mL}), 2 \mathrm{~N} \mathrm{NaOH}(3 \times 25 \mathrm{~mL})$, and brine $(3 \times 25 \mathrm{~mL})$. The organic phase was dried, filtered and concentrated, and the resulting residue was chromatographed (flash, $\mathrm{SiO}_{2}$ ) to give the enyne.

\section{Characterization data for enynes $5,6,12,13 a$, and $13 b$}

2-Allyl-3-[2-\{N-(2-propynyl)-N-(tert-butoxycarbonyl)amino\}ethyl]-1(phenylsulfonyl)indole (5). Elution with 8:2 hexanes/AcOEt; Yellow oil: $0.42 \mathrm{~g}(86 \%)$; IR (neat) 3292, 2977, 1693, 1367, $1172 \mathrm{~cm}^{-1}$; ${ }^{1} \mathrm{H}$ NMR (400 $\mathrm{MHz}$, mixture of rotamers) $\delta 1.48(\mathrm{~s}, 9 \mathrm{H}), 2.19$ (broad signal, $1 \mathrm{H}), 2.94(\mathrm{t}$, $J=8.4 \mathrm{~Hz}, 2 \mathrm{H}$ ), 3.42 (dd, $J=7.0$ and $6.8 \mathrm{~Hz}, 2 \mathrm{H}$ ), 3.72 and 3.96 (2 broad signals, $2 \mathrm{H}$ ), $3.82(\mathrm{dt}, J=5.6$ and $1.6 \mathrm{~Hz}, 2 \mathrm{H}$ ), 5.03 (broad signal, $1 \mathrm{H}$ ), $5.04(\mathrm{~d}, J=9.6 \mathrm{~Hz}, 1 \mathrm{H}), 6.01(\mathrm{~m}, 1 \mathrm{H}), 7.25(\mathrm{td}, J=7.6$ and $1.2 \mathrm{~Hz}, 1 \mathrm{H})$, $7.29(\mathrm{t}, J=8.0 \mathrm{~Hz}, 1 \mathrm{H}), 7.37(\mathrm{t}, J=8.0 \mathrm{~Hz}, 2 \mathrm{H}), 7.49(\mathrm{t}, J=7.6 \mathrm{~Hz}, 1 \mathrm{H})$, 7.60 (broad signal, $1 \mathrm{H}$ ), $7.71(\mathrm{~d}, J=7.6 \mathrm{~Hz}, 2 \mathrm{H}), 8.18(\mathrm{~d}, J=8.4 \mathrm{~Hz}, 1 \mathrm{H})$; ${ }^{13} \mathrm{C}$ NMR (100.6 MHz, mixture of rotamers) $\delta 22.9$ and $23.4\left(\mathrm{CH}_{2}\right), 28.3$ (3 $\left.\mathrm{CH}_{3}\right), 30.1\left(\mathrm{CH}_{2}\right), 36.4$ and $37.5\left(\mathrm{CH}_{2}\right), 46.4$ and $46.8\left(\mathrm{CH}_{2}\right), 71.3$ and $71.9(\mathrm{CH}), 79.6(\mathrm{C}), 80.4(\mathrm{C}), 115.1(\mathrm{CH}), 116.1\left(\mathrm{CH}_{2}\right), 118.5(\mathrm{CH}), 119.0$ (C), $123.6(\mathrm{CH}), 124.4(\mathrm{CH}), 126.2(2 \mathrm{CH}), 129.0(2 \mathrm{CH}), 130.3(\mathrm{C})$, $133.5(\mathrm{CH}), 135.3(\mathrm{CH}$ and $\mathrm{C}), 136.6(\mathrm{C}), 138.9$ (C), 154.7 (C); ESIHRMS calcd for $\mathrm{C}_{27} \mathrm{H}_{31} \mathrm{~N}_{2} \mathrm{O}_{4} \mathrm{~S}: 479.1999[\mathrm{M}+\mathrm{H}]^{+}$, found: 479.1999 .

2-Allyl-3-[2-\{N-(2-proynyl)-N-(4-nitrophenylsulfonyl)amino\}ethyl]-1-

(phenylsulfonyl)indole (6). Elution with $2: 8$ hexanes $/ \mathrm{CH}_{2} \mathrm{Cl}_{2}$; Yellow oil: $0.38 \mathrm{~g}(66 \%) ; \mathrm{IR}$ (neat) $3288,3104,1530,1351,1166 \mathrm{~cm}^{-1} ;{ }^{1} \mathrm{H}$ NMR $(400$ $\mathrm{MHz}) \delta 2.07(\mathrm{t}, J=2.4 \mathrm{~Hz}, 1 \mathrm{H}), 2.99(\mathrm{~m}, 2 \mathrm{H}), 3.34(\mathrm{~m}, 2 \mathrm{H}), 3.83(\mathrm{dt}, J=$ 6.0 and $1.6 \mathrm{~Hz}, 2 \mathrm{H}), 4.09(\mathrm{~d}, J=2.4 \mathrm{~Hz}, 2 \mathrm{H}), 5.03(\mathrm{~m}, 2 \mathrm{H}), 6.01(\mathrm{~m}, 1 \mathrm{H})$, $7.27(\mathrm{td}, J=7.2$ and $1.2 \mathrm{~Hz}, 1 \mathrm{H}), 7.32(\mathrm{td}, J=7.2$ and $1.2 \mathrm{~Hz}, 1 \mathrm{H}), 7.40(\mathrm{t}$, $J=8.4 \mathrm{~Hz}, 2 \mathrm{H}), 7.50(\mathrm{~m}, 2 \mathrm{H}), 7.74(\mathrm{~d}, J=7.2 \mathrm{~Hz}, 2 \mathrm{H}), 7.96(\mathrm{~d}, J=8.4 \mathrm{~Hz}$, $2 \mathrm{H}), 8.19(\mathrm{~d}, J=7.6 \mathrm{~Hz}, 1 \mathrm{H}), 8.28(\mathrm{~d}, J=8.8 \mathrm{~Hz}, 2 \mathrm{H}) ;{ }^{13} \mathrm{C}$ NMR $(100.6$ $\mathrm{MHz}) \delta 24.0\left(\mathrm{CH}_{2}\right), 30.3\left(\mathrm{CH}_{2}\right), 37.3\left(\mathrm{CH}_{2}\right), 46.2\left(\mathrm{CH}_{2}\right), 74.6(\mathrm{CH}), 76.1$ $(\mathrm{C}), 115.2(\mathrm{CH}), 116.3\left(\mathrm{CH}_{2}\right), 117.6(\mathrm{C}), 118.3(\mathrm{CH}), 123.8(\mathrm{CH}), 124.1(2$ $\mathrm{CH}), 124.7(\mathrm{CH}), 126.4(2 \mathrm{CH}), 128.8(2 \mathrm{CH}), 129.2(2 \mathrm{CH}), 129.8(\mathrm{C})$, $133.7(\mathrm{CH}), 135.4(\mathrm{CH}), 135.7(\mathrm{C}), 136.5(\mathrm{C}), 138.9(\mathrm{C}), 144.5(\mathrm{C}), 150.1$ (C); ESI-HRMS calcd for $\mathrm{C}_{28} \mathrm{H}_{26} \mathrm{~N}_{3} \mathrm{O}_{6} \mathrm{~S}_{2}$ : $564.1258[\mathrm{M}+\mathrm{H}]^{+}$, found: 564.1263.

2-Allyl-3-[2-\{N-(4-nitrophenylsulfonyl)- $N$-(3-trimethylsilyl-2-

propynyl)amino\}ethyl]-1-(phenylsulfonyl)indole (12). Elution with 3:7 hexanes $/ \mathrm{CH}_{2} \mathrm{Cl}_{2}$; Yellow oil: $0.49 \mathrm{~g}(77 \%)$; IR (neat) 2961, 1531, 1448, $1351 \mathrm{~cm}^{-1} ;{ }^{1} \mathrm{H}$ NMR $(400 \mathrm{MHz}) \delta-0.01(\mathrm{~s}, 9 \mathrm{H}), 3.01(\mathrm{~m}, 2 \mathrm{H}), 3.37(\mathrm{~m}, 2 \mathrm{H})$, $3.85(\mathrm{dt}, J=6.0$ and $1.6 \mathrm{~Hz}, 2 \mathrm{H}), 4.16(\mathrm{~s}, 2 \mathrm{H}), 5.07(\mathrm{~m}, 2 \mathrm{H}), 6.04(\mathrm{~m}, 1 \mathrm{H})$, $7.27(\mathrm{td}, J=8.0$ and $1.2 \mathrm{~Hz}, 1 \mathrm{H}), 7.33(\mathrm{td}, J=8.4$ and $2.0 \mathrm{~Hz}, 1 \mathrm{H}), 7.41(\mathrm{t}$, $J=8.0 \mathrm{~Hz}, 2 \mathrm{H}), 7.52(\mathrm{~m}, 2 \mathrm{H}), 7.76(\mathrm{~d}, J=8.0 \mathrm{~Hz}, 2 \mathrm{H}), 7.99(\mathrm{~d}, J=9.2 \mathrm{~Hz}$, $2 \mathrm{H}), 8.20(\mathrm{~d}, J=8.4 \mathrm{~Hz}, 1 \mathrm{H}), 8.29(\mathrm{~d}, J=9.2 \mathrm{~Hz}, 2 \mathrm{H}) ;{ }^{13} \mathrm{C}$ NMR $(100.6$ $\mathrm{MHz}) \delta-0.5\left(3 \mathrm{CH}_{3}\right), 23.8\left(\mathrm{CH}_{2}\right), 30.2\left(\mathrm{CH}_{2}\right), 37.9\left(\mathrm{CH}_{2}\right), 45.8\left(\mathrm{CH}_{2}\right), 91.8$ $(\mathrm{C}), 97.1(\mathrm{C}), 115.1(\mathrm{CH}), 116.3\left(\mathrm{CH}_{2}\right), 117.5(\mathrm{C}), 118.2(\mathrm{CH}), 123.7(\mathrm{CH})$, $124.0(2 \mathrm{CH}), 124.6(\mathrm{CH}), 126.3(2 \mathrm{CH}), 128.8(2 \mathrm{CH}), 129.1(2 \mathrm{CH})$, $129.8(\mathrm{C}), 133.6(\mathrm{CH}), 135.2(\mathrm{CH}), 135.6(\mathrm{C}), 136.4(\mathrm{C}), 138.8(\mathrm{C}), 144.5$ (C), 150.0 (C); ESI-HRMS calcd for $\mathrm{C}_{31} \mathrm{H}_{34} \mathrm{~N}_{3} \mathrm{O}_{6} \mathrm{~S}_{2} \mathrm{Si}$ : $636.1653[\mathrm{M}+\mathrm{H}]^{+}$, found: 636.1636

\section{2-Allyl-3-[2-\{N-(2-butynyl)-N-(phenylsulfonyl)amino\}ethyl]-1-}

(phenylsulfonyl)indole (13a). Elution with $2: 8$ hexanes $/ \mathrm{CH}_{2} \mathrm{Cl}_{2}$; Yellow oil: $0.30 \mathrm{~g}(56 \%) ;$ IR (neat) 3066, 2921, 1447, 1364, $1163 \mathrm{~cm}^{-1} ;{ }^{1} \mathrm{H}$ NMR (400 $\mathrm{MHz}) \delta 1.57(\mathrm{t}, J=2.4 \mathrm{~Hz}, 3 \mathrm{H}), 2.98(\mathrm{~m}, 2 \mathrm{H}), 3.30(\mathrm{~m}, 2 \mathrm{H}), 3.84(\mathrm{dt}, J=$ 5.6 and $1.6 \mathrm{~Hz}, 2 \mathrm{H}), 4.03(\mathrm{q}, J=2.4 \mathrm{~Hz}, 2 \mathrm{H}), 5.06(\mathrm{~m}, 2 \mathrm{H}), 6.03(\mathrm{~m}, 1 \mathrm{H})$, $7.29(\mathrm{~m}, 2 \mathrm{H}), 7.39(\mathrm{t}, J=8.4 \mathrm{~Hz}, 2 \mathrm{H}), 7.47(\mathrm{~m}, 2 \mathrm{H}), 7.52(\mathrm{~m}, 3 \mathrm{H}), 7.73(\mathrm{~d}$, $J=8.4 \mathrm{~Hz}, 2 \mathrm{H}), 7.80(\mathrm{~d}, J=7.2 \mathrm{~Hz}, 2 \mathrm{H}), 8.19(\mathrm{~d}, J=7.2 \mathrm{~Hz}, 1 \mathrm{H}) ;{ }^{13} \mathrm{C}$ NMR $(100.6 \mathrm{MHz}) \delta 3.2\left(\mathrm{CH}_{3}\right), 24.0\left(\mathrm{CH}_{2}\right), 30.2\left(\mathrm{CH}_{2}\right), 37.8\left(\mathrm{CH}_{2}\right), 46.0$ $\left(\mathrm{CH}_{2}\right), 71.7(\mathrm{C}), 81.8(\mathrm{C}), 115.1(\mathrm{CH}), 116.2\left(\mathrm{CH}_{2}\right), 118.2(\mathrm{C}), 118.4(\mathrm{CH})$, 123.6 (CH), $124.5(\mathrm{CH}), 126.3(2 \mathrm{CH}), 127.5(2 \mathrm{CH}), 128.7(2 \mathrm{CH}), 129.1$ (2 CH), $130.0(\mathrm{C}), 132.5(\mathrm{CH}), 133.6(\mathrm{CH}), 135.3(\mathrm{CH}), 135.5(\mathrm{C}), 136.5$ (C), 138.7 (C), 138.9 (C); ESI-HRMS calcd for $\mathrm{C}_{29} \mathrm{H}_{29} \mathrm{~N}_{2} \mathrm{O}_{4} \mathrm{~S}_{2}: 533.1563$ $[\mathrm{M}+\mathrm{H}]^{+}$, found: 533.1557 . 
2-Allyl-3-[2-\{N-(2-butynyl)-N-(4-nitrophenylsulfonyl)amino\}ethyl]-1(phenylsulfonyl)indole (13b). Elution with 6:4 hexanes/ $\mathrm{Et}_{2} \mathrm{O}$; Yellow oil: $0.26 \mathrm{~g} \mathrm{(45 \% );} \mathrm{IR} \mathrm{(neat)} \mathrm{3104,} \mathrm{2921,} \mathrm{1530,} 1350 \mathrm{~cm}^{-1} ;{ }^{1} \mathrm{H}$ NMR $(400 \mathrm{MHz})$ $\delta 1.56(\mathrm{t}, J=2.4 \mathrm{~Hz}, 3 \mathrm{H}), 2.97(\mathrm{~m}, 2 \mathrm{H}), 3.31(\mathrm{~m}, 2 \mathrm{H}), 3.83(\mathrm{dt}, J=6.0$ and $1.6 \mathrm{~Hz}, 2 \mathrm{H}), 4.05(\mathrm{q}, J=2.4 \mathrm{~Hz}, 2 \mathrm{H}), 5.04(\mathrm{~m}, 2 \mathrm{H}), 6.02(\mathrm{~m}, 1 \mathrm{H})$ $7.26(\mathrm{td}, J=7.6$ and $1.2 \mathrm{~Hz}, 1 \mathrm{H}), 7.31(\mathrm{td}, J=7.6$ and $1.2 \mathrm{~Hz}, 1 \mathrm{H}), 7.40$ (t, $J=8.0 \mathrm{~Hz}, 2 \mathrm{H}), 7.50(\mathrm{~m}, 2 \mathrm{H}), 7.74(\mathrm{~d}, J=8.0 \mathrm{~Hz}, 2 \mathrm{H}), 7.96(\mathrm{~d}, J=8.8 \mathrm{~Hz}$, $2 \mathrm{H}), 8.18(\mathrm{~d}, J=7.2 \mathrm{~Hz}, 1 \mathrm{H}), 8.27(\mathrm{~d}, J=8.4 \mathrm{~Hz}, 2 \mathrm{H}) ;{ }^{13} \mathrm{C}$ NMR $(100.6$ $\mathrm{MHz}) \delta 3.2\left(\mathrm{CH}_{3}\right), 24.0\left(\mathrm{CH}_{2}\right), 30.2\left(\mathrm{CH}_{2}\right), 37.8\left(\mathrm{CH}_{2}\right), 46.0\left(\mathrm{CH}_{2}\right), 71.4$ $(\mathrm{C}), 82.4(\mathrm{C}), 115.2(\mathrm{CH}), 116.2\left(\mathrm{CH}_{2}\right), 117.7(\mathrm{C}), 118.2(\mathrm{CH}), 123.7(\mathrm{CH})$ $123.8(2 \mathrm{CH}), 124.6(\mathrm{CH}), 126.3(2 \mathrm{CH}), 128.8(2 \mathrm{CH}), 129.2(2 \mathrm{CH})$, $129.8(\mathrm{C}), 133.6(\mathrm{CH}), 135.4(\mathrm{CH}), 135.6(\mathrm{C}), 136.5(\mathrm{C}), 138.9(\mathrm{C}), 144.7$ (C), 150.0 (C); ESI-HRMS calcd for $\mathrm{C}_{29} \mathrm{H}_{28} \mathrm{~N}_{3} \mathrm{O}_{6} \mathrm{~S}_{2}$ : $578.1414[\mathrm{M}+\mathrm{H}]^{+}$, found: 578.1414 .

\section{General procedure for the preparation of haloenynes $17-\mathrm{Br}, 17-\mathrm{I}$ and 17-Cl}

2-Allyl-3-[2-\{N-(2-propynyl)-N-(p-toluensulfonyl)amino\}ethyl]-1-

(phenylsulfonyl)indole (16) was prepared following the general procedure previously described for the preparation of enynes. Elution with $2: 8$ hexanes $/ \mathrm{CH}_{2} \mathrm{Cl}_{2}$; Yellow oil: $0.44 \mathrm{~g}(82 \%)$; IR (neat) 3286, 2925, 1448 , 1348, $1159 \mathrm{~cm}^{-1}$; ${ }^{1} \mathrm{H}$ NMR $(400 \mathrm{MHz}) \delta 2.14(\mathrm{t}, J=2.8 \mathrm{~Hz}, 1 \mathrm{H}), 2.41(\mathrm{~s}$, $3 \mathrm{H}), 3.02(\mathrm{~m}, 2 \mathrm{H}), 3.33(\mathrm{~m}, 2 \mathrm{H}), 3.86(\mathrm{dt}, J=5.6$ and $1.6 \mathrm{~Hz}, 2 \mathrm{H}), 4.08(\mathrm{~d}$ $J=2.8 \mathrm{~Hz}, 2 \mathrm{H}), 5.08(\mathrm{~m}, 2 \mathrm{H}), 6.04(\mathrm{~m}, 1 \mathrm{H}), 7.25-7.35(\mathrm{~m}, 4 \mathrm{H}), 7.40(\mathrm{t}, J$ $=8.4 \mathrm{~Hz}, 2 \mathrm{H}), 7.53(\mathrm{~m}, 2 \mathrm{H}), 7.70(\mathrm{~d}, J=8 \mathrm{~Hz}, 2 \mathrm{H}), 7.75(\mathrm{~d}, J=8 \mathrm{~Hz}, 2 \mathrm{H})$, $8.21(\mathrm{~d}, J=7.6 \mathrm{~Hz}, 1 \mathrm{H}) ;{ }^{13} \mathrm{C}$ NMR $(100.6 \mathrm{MHz}) \delta 21.4\left(\mathrm{CH}_{3}\right), 24.0\left(\mathrm{CH}_{2}\right)$, $30.1\left(\mathrm{CH}_{2}\right), 37.2\left(\mathrm{CH}_{2}\right), 46.1\left(\mathrm{CH}_{2}\right), 73.8(\mathrm{CH}), 76.8(\mathrm{C}), 115.0(\mathrm{CH})$ $116.2\left(\mathrm{CH}_{2}\right), 118.1(\mathrm{C}), 118.4(\mathrm{CH}), 123.6(\mathrm{CH}), 124.4(\mathrm{CH}), 126.2(2$ $\mathrm{CH}), 127.4(2 \mathrm{CH}), 129.1(2 \mathrm{CH}), 129.4(2 \mathrm{CH}), 129.9(\mathrm{C}), 133.5(\mathrm{CH})$ $135.3(\mathrm{CH}), 135.5(\mathrm{C}), 135.6(\mathrm{C}), 136.4(\mathrm{C}), 138.8(\mathrm{C}), 143.6(\mathrm{C})$; ESIHRMS calcd for $\mathrm{C}_{29} \mathrm{H}_{29} \mathrm{~N}_{2} \mathrm{O}_{4} \mathrm{~S}_{2}: 533.1563[\mathrm{M}+\mathrm{H}]^{+}$, found: 533.1554 .

The corresponding succinimide $(0.22 \mathrm{mmol})$ and either $\mathrm{AgNO}_{3}(0.02$ $\mathrm{mmol})$ or $\mathrm{AgOAc}(0.02 \mathrm{mmol})$ were added to a solution of enyne $16(0.11$ $\mathrm{g}, 0.20 \mathrm{mmol})$ in acetone $(1 \mathrm{~mL})$. After being stirred at it for $2 \mathrm{~h}$, the reaction mixture was diluted with $\mathrm{Et}_{2} \mathrm{O}(15 \mathrm{~mL})$ and washed with brine (2 $x 15 \mathrm{~mL}$ ). The organic phase was dried, filtered and concentrated, and the resulting residue was chromatographed (flash, $\mathrm{SiO}_{2}$ ) to give enynes $17-X$.

\section{Characterization data for haloenynes $17-\mathrm{Br}, 17-\mathrm{I}$ and $17-\mathrm{Cl}$}

2-Allyl-3-[2-\{N-(3-bromo-2-proynyl)-N-(p-toluensulfonyl)\}aminoethyl]-1(phenylsulfonyl)indole (17-Br). Elution with $1: 9$ hexanes $/ \mathrm{CH}_{2} \mathrm{Cl}_{2}$. Yellow oil: $106 \mathrm{mg}(87 \%)$; IR (neat) 3065, 2926, 1448, 1348, $1160 \mathrm{~cm}^{-1} ;{ }^{1} \mathrm{H}$ NMR $(400 \mathrm{MHz}) \delta 2.39(\mathrm{~s}, 3 \mathrm{H}), 2.95(\mathrm{~m}, 2 \mathrm{H}), 3.25(\mathrm{~m}, 2 \mathrm{H}), 3.82(\mathrm{dt}, J=6.0$ and $1.6 \mathrm{~Hz}, 2 \mathrm{H}), 4.02(\mathrm{~s}, 2 \mathrm{H}), 5.03(\mathrm{~m}, 2 \mathrm{H}), 6.02(\mathrm{~m}, 1 \mathrm{H}), 7.25-7.32(\mathrm{~m}$, $4 \mathrm{H}), 7.38(\mathrm{t}, J=7.6 \mathrm{~Hz}, 2 \mathrm{H}), 7.50(\mathrm{~m}, 2 \mathrm{H}), 7.65(\mathrm{~d}, J=8.4 \mathrm{~Hz}, 2 \mathrm{H}), 7.72$ $(\mathrm{d}, J=8.4 \mathrm{~Hz}, 2 \mathrm{H}), 8.18(\mathrm{~d}, J=8.0 \mathrm{~Hz}, 1 \mathrm{H}) ;{ }^{13} \mathrm{C}$ NMR $(100.6 \mathrm{MHz}) \delta 21.5$ $\left(\mathrm{CH}_{3}\right), 24.1\left(\mathrm{CH}_{2}\right), 30.2\left(\mathrm{CH}_{2}\right), 38.5\left(\mathrm{CH}_{2}\right), 45.4(\mathrm{C}), 46.3\left(\mathrm{CH}_{2}\right), 73.2(\mathrm{C})$, $115.2(\mathrm{CH}), 116.3\left(\mathrm{CH}_{2}\right), 118.1(\mathrm{C}), 118.5(\mathrm{CH}), 123.8(\mathrm{CH}), 124.6(\mathrm{CH})$, $126.3(2 \mathrm{CH}), 127.6(2 \mathrm{CH}), 129.2(2 \mathrm{CH}), 129.6(2 \mathrm{CH}), 130.0(\mathrm{C}), 133.7$ $(\mathrm{CH}), 135.4(\mathrm{CH}$ and $\mathrm{C}), 135.6(\mathrm{C}), 136.6(\mathrm{C}), 138.9(\mathrm{C}), 143.8(\mathrm{C})$; ESIHRMS calcd for $\mathrm{C}_{29} \mathrm{H}_{28} \mathrm{BrN}_{2} \mathrm{O}_{4} \mathrm{~S}_{2}: 611.0668[\mathrm{M}+\mathrm{H}]^{+}$, found: 611.0671 .

2-Allyl-3-[N-(3-iodo-2-proynyl)-N-tosyl-2-aminoethyl]-1-

(phenylsulfonyl)indole (17-I). Elution with $1: 9$ hexanes $/ \mathrm{CH}_{2} \mathrm{Cl}_{2}$. Yellow oil: $117 \mathrm{mg}$ (89\%); IR (neat) 2925, 1448, 1347, $1159 \mathrm{~cm}^{-1} ;{ }^{1} \mathrm{H}$ NMR (400 $\mathrm{MHz}) \delta 2.40(\mathrm{~s}, 3 \mathrm{H}), 2.95(\mathrm{~m}, 2 \mathrm{H}), 3.26(\mathrm{~m}, 2 \mathrm{H}), 3.81(\mathrm{~d}, J=6.0 \mathrm{~Hz}, 2 \mathrm{H})$, $4.14(\mathrm{~s}, 2 \mathrm{H}), 5.03(\mathrm{~m}, 2 \mathrm{H}), 6.02(\mathrm{~m}, 1 \mathrm{H}), 7.25-7.32(\mathrm{~m}, 4 \mathrm{H}), 7.39(\mathrm{t}, J=$ $7.6 \mathrm{~Hz}, 2 \mathrm{H}), 7.49(\mathrm{~m}, 2 \mathrm{H}), 7.64(\mathrm{~d}, J=8.0 \mathrm{~Hz}, 2 \mathrm{H}), 7.72(\mathrm{~d}, J=8.0 \mathrm{~Hz}$, $2 \mathrm{H}), 8.19(\mathrm{~d}, J=8.4 \mathrm{~Hz}, 1 \mathrm{H}) ;{ }^{13} \mathrm{C} \operatorname{NMR}(100.6 \mathrm{MHz}) \delta 2.2(\mathrm{C}), 21.5\left(\mathrm{CH}_{3}\right)$,
$24.0\left(\mathrm{CH}_{2}\right), 30.2\left(\mathrm{CH}_{2}\right), 39.2\left(\mathrm{CH}_{2}\right), 46.3\left(\mathrm{CH}_{2}\right), 87.0(\mathrm{C}), 115.1(\mathrm{CH})$, $116.3\left(\mathrm{CH}_{2}\right), 118.1(\mathrm{C}), 118.5(\mathrm{CH}), 123.8(\mathrm{CH}), 124.5(\mathrm{CH}), 126.3(2$ $\mathrm{CH}), 127.6(2 \mathrm{CH}), 129.1(2 \mathrm{CH}), 129.6(2 \mathrm{CH}), 130.0(\mathrm{C}), 133.6(\mathrm{CH})$, $135.3(\mathrm{CH}$ and $\mathrm{C}), 135.6(\mathrm{C}), 136.5(\mathrm{C}), 138.9(\mathrm{C}), 143.7(\mathrm{C})$; ESI-HRMS calcd for $\mathrm{C}_{29} \mathrm{H}_{28} \mathrm{IN}_{2} \mathrm{O}_{4} \mathrm{~S}_{2}: 659.053[\mathrm{M}+\mathrm{H}]^{+}$, found: 659.0531 .

2-Allyl-3-[N-(3-chloro-2-proynyl)-N-tosyl-2-aminoethyl]-1-

(phenylsulfonyl)indole (17-CI). Elution with $1: 9$ hexanes $/ \mathrm{CH}_{2} \mathrm{Cl}_{2}$. Yellow oil: $69 \mathrm{mg}(61 \%)$; IR (neat) 3065, 2926, 1448, 1349, $1160 \mathrm{~cm}^{-1} ;{ }^{1} \mathrm{H}$ NMR $(400 \mathrm{MHz}) \delta 2.39(\mathrm{~s}, 3 \mathrm{H}), 2.95(\mathrm{~m}, 2 \mathrm{H}), 3.25(\mathrm{~m}, 2 \mathrm{H}), 3.82(\mathrm{dt}, J=5.6$ and $1.6 \mathrm{~Hz}, 2 \mathrm{H}), 4.00(\mathrm{~s}, 2 \mathrm{H}), 5.02(\mathrm{~m}, 2 \mathrm{H}), 6.01(\mathrm{~m}, 1 \mathrm{H}), 7.25-7.32(\mathrm{~m}$, 4H), 7.38 (t, $J=8.4 \mathrm{~Hz}, 2 \mathrm{H}), 7.49(\mathrm{~m}, 2 \mathrm{H}), 7.65(\mathrm{~d}, J=8.4 \mathrm{~Hz}, 2 \mathrm{H}), 7.72$ $(\mathrm{d}, J=8.4 \mathrm{~Hz}, 2 \mathrm{H}), 8.18(\mathrm{~d}, J=8.4 \mathrm{~Hz}, 1 \mathrm{H}) ;{ }^{13} \mathrm{C}$ NMR $(100.6 \mathrm{MHz}) \delta 21.5$ $\left(\mathrm{CH}_{3}\right), 24.2\left(\mathrm{CH}_{2}\right), 30.3\left(\mathrm{CH}_{2}\right), 37.8\left(\mathrm{CH}_{2}\right), 46.3\left(\mathrm{CH}_{2}\right), 62.7(\mathrm{C}), 63.7(\mathrm{C})$, $115.2(\mathrm{CH}), 116.2\left(\mathrm{CH}_{2}\right), 118.2(\mathrm{C}), 118.4(\mathrm{CH}), 123.8(\mathrm{CH}), 124.6(\mathrm{CH})$, $126.3(2 \mathrm{CH}), 127.5(2 \mathrm{CH}), 129.2(2 \mathrm{CH}), 129.6(2 \mathrm{CH}), 130.0(\mathrm{C}), 133.7$ $(\mathrm{CH}), 135.4(\mathrm{CH}$ and $\mathrm{C}), 135.6(\mathrm{C}), 136.6(\mathrm{C}), 138.9(\mathrm{C}), 143.8(\mathrm{C})$; ESIHRMS calcd for $\mathrm{C}_{29} \mathrm{H}_{28} \mathrm{CIN}_{2} \mathrm{O}_{4} \mathrm{~S}_{2}: 567.1174[\mathrm{M}+\mathrm{H}]^{+}$, found: 567.1185 .

\section{General procedure for the RCEYM reactions}

A solution of the corresponding enyne $(0.10 \mathrm{mmol})$ and the $\mathrm{Ru}$ catalyst $(7.5 \mathrm{~mol} \%)$ in the indicated solvent $(110 \mathrm{~mL})$ was stirred at reflux under Ar. Additional portions of the catalyst were added at regular intervals (12 h) until completion of the reaction by TLC (see Tables 1-3). The reaction mixture was concentrated, and the resulting residue was chromatographed (flash, $\mathrm{SiO}_{2}$ ).

\section{Characterization data for $7 Z, 7 E, 8,8^{\prime}$, and 9}

(E)-3-(4-Nitrophenylsulfonyl)-8-(phenylsulfonyl)-5-(vinyl)-2,3,4,7tetrahydro-1 $(H)$-azonino[5,4-b]indole (7E). $7 E$ was isolated as a colorless oil $(9 \%)$ from the crude reaction mixture corresponding to entry 5 of Table 1 ; IR (neat) $3105,2927,1531,1446, \mathrm{~cm}^{-1}$; ${ }^{1} \mathrm{H}$ NMR $(400 \mathrm{MHz}$, assignment aided by $\mathrm{HSQC}$ and $\left.\operatorname{COSY}{ }^{1} \mathrm{H}-{ }^{1} \mathrm{H}\right) \delta 2.70(\mathrm{~m}, 1 \mathrm{H}, \mathrm{H}-1), 2.75$ (m, $1 \mathrm{H}, \mathrm{H}-2), 2.99$ (ddd, $J=15.6,9.6$, and $6.0 \mathrm{~Hz}, 1 \mathrm{H}, \mathrm{H}-1), 3.25(\mathrm{~d}, J=$ $11.6 \mathrm{~Hz}, 1 \mathrm{H}, \mathrm{H}-4$ ), 3.84 (ddd, $J=15.2,10.0$, and $4.8 \mathrm{~Hz}, 1 \mathrm{H}, \mathrm{H}-2$ ). 3.99 (dd, $J=16.4$ and $12 \mathrm{~Hz}, 1 \mathrm{H}, \mathrm{H}-7), 4.27(\mathrm{dd}, J=16.4$ and $4.8 \mathrm{~Hz}, 1 \mathrm{H}, \mathrm{H}-$ 7), 4.75 (d, $J=11.2 \mathrm{~Hz}, 1 \mathrm{H}, \mathrm{H}-4), 5.37$ (d, $\left.J=10.4 \mathrm{~Hz}, 1 \mathrm{H}, \mathrm{CH}_{2}=\right), 5.74$ (d, $J=17.2 \mathrm{~Hz}, 1 \mathrm{H}, \mathrm{CH}_{2}=$ ), $5.78(\mathrm{dd}, J=11.2$ and $4.8 \mathrm{~Hz}, 1 \mathrm{H}, \mathrm{H}-6), 6.60$ (dd, $J=17.6$ and $11.2 \mathrm{~Hz}, 1 \mathrm{H}, \mathrm{CH}=), 7.24(\mathrm{td}, J=7.6$ and $1.2 \mathrm{~Hz}, 1 \mathrm{H}, \mathrm{H}-$ 11), $7.30(\mathrm{td}, J=7.6$ and $1.6 \mathrm{~Hz}, 1 \mathrm{H}, \mathrm{H}-10), 7.33(\mathrm{~d}, J=7.6 \mathrm{~Hz}, 1 \mathrm{H}, \mathrm{H}-$ 12), 7.41 (t, $J=7.6 \mathrm{~Hz}, 2 \mathrm{H}, \mathrm{Ph}), 7.54$ (t, $J=8.0 \mathrm{~Hz}, 1 \mathrm{H}, \mathrm{Ph}), 7.70$ (d, $J=$ $7.2 \mathrm{~Hz}, 2 \mathrm{H}, \mathrm{Ph}), 7.96(\mathrm{~d}, J=8.8 \mathrm{~Hz}, 2 \mathrm{H}, \mathrm{Ph}), 8.18(\mathrm{~d}, J=8.4 \mathrm{~Hz}, 1 \mathrm{H}, \mathrm{H}-$ 9), $8.34(\mathrm{~d}, J=8.8 \mathrm{~Hz}, 2 \mathrm{H}, \mathrm{Ph}) ;{ }^{13} \mathrm{C} \mathrm{NMR}(100.6 \mathrm{MHz}) \delta 25.8\left(\mathrm{CH}_{2}, \mathrm{C}-1\right)$, $26.9\left(\mathrm{CH}_{2}, \mathrm{C}-7\right), 48.9\left(\mathrm{CH}_{2}, \mathrm{C}-2\right), 53.3\left(\mathrm{CH}_{2}, \mathrm{C}-4\right), 115.2(\mathrm{CH}, \mathrm{C}-9), 117.7$ $(\mathrm{CH}, \mathrm{C}-12), 118.3\left(\mathrm{CH}_{2}, \mathrm{CH}_{2}=\right), 123.2(\mathrm{C}, \mathrm{C}-12 \mathrm{~b}), 123.8(\mathrm{CH}, \mathrm{C}-11)$, 124.5 (2 CH, Ph), 125.0 (CH, C-10), 126.2 (2 CH, Ph), $128.1(2 \mathrm{CH}, \mathrm{Ph})$, 129.3 (2 CH, Ph), 130.9 (C, C-12a), $131.0(\mathrm{CH}, \mathrm{CH}=), 133.4$ (C, C-5), 133.7 (C, Ph), 133.9 ( $\mathrm{CH}$ and $\mathrm{C}, \mathrm{C}-6$ and $\mathrm{Ph}), 136.3$ (C, C-8a), 138.8 (C, C-7a), 144.7 (C, Ph), 150.0 (C, Ph); ESI-HRMS calcd for $\mathrm{C}_{28} \mathrm{H}_{26} \mathrm{~N}_{3} \mathrm{O}_{6} \mathrm{~S}_{2}$ : $564.1258[\mathrm{M}+\mathrm{H}]^{+}$, found: 564.1256 .

(Z)-3-(4-Nitrophenylsulfonyl)-8-(phenylsulfonyl)-5-(vinyl)-2,3,4,7tetrahydro-1(H)-azonino[5,4-b]indole (7Z) and 3-(4-Nitrophenylsulfonyl)8-(phenylsulfonyl)-5-(2-phenylvinyl)-2,3,4,7-tetrahydro-1(H)-azonino[5,4b]indole (8). A 1:1 mixture of $\mathbf{7 Z}$ and $\mathbf{8}$ was obtained (20\% overall combined yield) from the crude reaction mixture corresponding to entry 5 of Table 1. ${ }^{1} \mathrm{H}$ NMR (400 MHz, assignment aided by HSQC) $\delta 2.96(\mathrm{~m}$, $4 \mathrm{H}, 7 \mathrm{Z} / 8$ ), 3.48 (t, J=6.0 Hz, 2H, 7Z), 3.55 (t, J=6.0 Hz, 2H, 8), 3.93 (d, $J=7.6 \mathrm{~Hz}, 2 \mathrm{H}, 7 \mathrm{Z}$ ), 3.95 (s, 2H, 7Z), 3.97 (d, $J=8.2 \mathrm{~Hz}, 2 \mathrm{H}, 8), 4.10$ (s, $2 \mathrm{H}, 8), 5.06(\mathrm{~d}, J=11.2 \mathrm{~Hz}, 1 \mathrm{H}, 7 Z), 5.24(\mathrm{~d}, J=17.6 \mathrm{~Hz}, 1 \mathrm{H}, 7 Z), 6.20$ (t, $J=7.6 \mathrm{~Hz}, 1 \mathrm{H}, 7 \mathrm{7}), 6.30(\mathrm{t}, J=8.2 \mathrm{~Hz}, 1 \mathrm{H}, 8), 6.34(\mathrm{dd}, J=17.6$ and 
$11.2 \mathrm{~Hz}, 1 \mathrm{H}, 7 Z), 6.58(\mathrm{~d}, J=16.4 \mathrm{~Hz}, 1 \mathrm{H}, 8), 6.70(\mathrm{~d}, J=16.4 \mathrm{~Hz}, 1 \mathrm{H}$, 8), 7.20-7.40 (m, 15H, 7Z/8), $7.50(\mathrm{~m}, 2 \mathrm{H}, 7 \mathrm{Z} / 8), 7.72(\mathrm{~m}, 4 \mathrm{H}, 7 \mathrm{Z} / 8), 7.77$ and $7.81(2 \mathrm{~d}, J=8.8 \mathrm{~Hz}, 4 \mathrm{H}, 7 \mathrm{Z} / 8), 8.07(\mathrm{t}, J=8.4 \mathrm{~Hz}, 2 \mathrm{H}, 7 \mathrm{Z} / 8), 8.17$ and $8.21(2 \mathrm{~d}, J=8.8 \mathrm{~Hz}, 4 \mathrm{H}, 7 \mathrm{Z} / 8) ;{ }^{13} \mathrm{C} \mathrm{NMR}(100.6 \mathrm{MHz}$, assignment aided by HSQC, aromatic signals are not assigned) $\delta 22.8\left(\mathrm{CH}_{2}, 8\right), 23.0$ $\left(\mathrm{CH}_{2}, 7 \mathrm{Z}\right), 25.3\left(\mathrm{CH}_{2}, 7 \mathrm{Z}\right), 25.5\left(\mathrm{CH}_{2}, 8\right), 44.3\left(\mathrm{CH}_{2}, 7 \mathrm{Z}\right), 44.5\left(\mathrm{CH}_{2}, 8\right)$, $48.2\left(\mathrm{CH}_{2}, 8\right), 48.4\left(\mathrm{CH}_{2}, 7 Z\right), 112.9\left(\mathrm{CH}_{2}, 7 \mathrm{Z}\right), 114.9(\mathrm{CH}), 117.8(\mathrm{CH})$, $117.9(\mathrm{CH}), 117.9(\mathrm{C}), 118.0(\mathrm{C}), 123.6(\mathrm{CH}), 123.7(\mathrm{CH}), 124.0(\mathrm{CH})$ $124.1(\mathrm{CH}), 124.7(\mathrm{CH}), 124.8(\mathrm{CH}), 126.2(\mathrm{CH}), 126.3(\mathrm{CH}), 127.7(\mathrm{CH})$ $128.0(\mathrm{CH}, 8), 128.3(\mathrm{CH}), 128.4(\mathrm{CH}), 128.7(\mathrm{CH}), 129.0(\mathrm{C}), 129.3$ $(\mathrm{CH}), 130.7(\mathrm{CH}, 8), 132.4(\mathrm{C}), 133.8(\mathrm{CH}, 7 \mathrm{7} / 8), 134.0(\mathrm{C}, 8), 134.1(\mathrm{C}$, 7Z), $135.0(\mathrm{C}), 136.0(\mathrm{C}), 136.9(\mathrm{C}), 138.8(\mathrm{C}), 138.9(\mathrm{CH}, 7 Z), 144.5(\mathrm{C})$ 144.7 (C), 149.8 (C); ESI-HRMS calcd for $\mathrm{C}_{28} \mathrm{H}_{26} \mathrm{~N}_{3} \mathrm{O}_{6} \mathrm{~S}_{2}: 564.1258$ (7Z, $\left.[\mathrm{M}+\mathrm{H}]^{+}\right)$, found: 564.1251 ; ESI-HRMS calcd for $\mathrm{C}_{34} \mathrm{H}_{30} \mathrm{~N}_{3} \mathrm{O}_{6} \mathrm{~S}_{2}: 640.1571$ $\left(8,[\mathrm{M}+\mathrm{H}]^{+}\right)$, found: 640.1559 .

\section{5-[2-(2-isopropoxyphenyl)vinyl]-3-(4-nitrophenylsulfonyl)-8-}

(phenylsulfonyl)-2,3,4,7-tetrahydro-1(H)-azonino[5,4-b]indole 8'. Signals from a $1: 1$ mixture of $\mathbf{7 Z}$ and $\mathbf{8}$ ' obtained from the crude reaction mixture corresponding to entry 6 of Table 1 (20\% overall combined yield). ${ }^{1} \mathrm{H}$ NMR (400 MHz, aromatic signals are not shown) $\delta 1.34(\mathrm{~d}, J=5.6 \mathrm{~Hz}$, 6H), $2.97(\mathrm{~m}, 2 \mathrm{H}), 3.49(\mathrm{~m}, 2 \mathrm{H}), 4.01(\mathrm{~d}, \mathrm{~J}=8.0 \mathrm{~Hz}, 2 \mathrm{H}), 4.09(\mathrm{~s}, 2 \mathrm{H})$, $4.55(\mathrm{~h}, J=5.6 \mathrm{~Hz}, 1 \mathrm{H}), 6.26(\mathrm{t}, J=8.4 \mathrm{~Hz}, 1 \mathrm{H}), 6.72(\mathrm{~d}, J=16.4 \mathrm{~Hz}, 1 \mathrm{H})$ $6.98(\mathrm{~d}, J=16.4 \mathrm{~Hz}, 1 \mathrm{H}), 6.46(\mathrm{~s}, 1 \mathrm{H})$.

Dimer 9 was isolated as a yellow oil (16\%) from the crude reaction mixture corresponding to entry 5 of Table 1; IR (neat) 3027, 1606, 1530, $1448, \mathrm{~cm}^{-1}$; ${ }^{1} \mathrm{H}$ NMR (400 MHz, assignment aided by HSQC) $\delta 3.01$ (t, $J$ $=6.0 \mathrm{~Hz}, 4 \mathrm{H}), 3.48(\mathrm{t}, J=6.0 \mathrm{~Hz}, 4 \mathrm{H}), 3.85(\mathrm{~s}, 4 \mathrm{H}) ; 3.95(\mathrm{~d}, J=7.6 \mathrm{~Hz}$, $4 \mathrm{H}), 6.20(\mathrm{t}, J=7.6 \mathrm{~Hz}, 2 \mathrm{H}), 6.22(\mathrm{~s}, 2 \mathrm{H}), 7.21(\mathrm{t}, J=7.6 \mathrm{~Hz}, 2 \mathrm{H}), 7.26$ $(\mathrm{m}, 2 \mathrm{H}), 7.30$ (t, J=7.2 Hz, 2H), 7.39 (t, J=8.0 Hz, 4H), 7.51 (t, J=7.6 $\mathrm{Hz}, 2 \mathrm{H}), 7.71(\mathrm{~d}, J=8.4 \mathrm{~Hz}, 4 \mathrm{H}), 7.81(\mathrm{~d}, J=9.2 \mathrm{~Hz}, 4 \mathrm{H}), 8.05(\mathrm{~d}, J=8.4$ $\mathrm{Hz}, 2 \mathrm{H}), 8.20(\mathrm{~d}, J=8.4 \mathrm{~Hz}, 4 \mathrm{H}) ;{ }^{13} \mathrm{C} \operatorname{NMR}(100.6 \mathrm{MHz}) \delta 23.5\left(\mathrm{CH}_{2}\right)$, $25.4\left(\mathrm{CH}_{2}\right), 45.3\left(\mathrm{CH}_{2}\right), 48.6\left(\mathrm{CH}_{2}\right), 114.9(\mathrm{CH}), 117.7(\mathrm{C}), 117.9(\mathrm{CH})$, $123.7(\mathrm{CH}), 124.2(2 \mathrm{CH}), 124.8(\mathrm{CH}), 126.3(2 \mathrm{CH}), 128.4(2 \mathrm{CH}), 128.8$ (C), $129.4(2 \mathrm{CH}), 130.2(\mathrm{CH}), 132.4(\mathrm{CH}), 133.8(\mathrm{CH}), 134.0(\mathrm{C}), 135.2$ (C), 136.1 (C), 138.8 (C), 144.1 (C), 149.9 (C); ESI-HRMS calcd for $\mathrm{C}_{54} \mathrm{H}_{50} \mathrm{~N}_{7} \mathrm{O}_{12} \mathrm{~S}_{4}: 1116.2394\left[\mathrm{M}+\mathrm{NH}_{4}\right]^{+}$, found: 1116.2370 .

\section{Metathesis reaction of 6 under ethylene}

\section{2-Allyl-3-[2-\{N-(2-methylen-3-butenyl)-N-(4-}

nitrophenylsulfonyl)amino\}ethyl]-1-(phenylsulfonyl)indole (10). A solution of enyne 6 (53 mg, $0.09 \mathrm{mmol})$ and the catalyst G2 (12 mg, $15 \mathrm{~mol} \%$ ) in $\mathrm{CH}_{2} \mathrm{Cl}_{2}(100 \mathrm{~mL})$ was stirred at $\mathrm{rt}$ under ethylene for $3 \mathrm{~h}$. The reaction mixture was concentrated and the resulting residue was chromatographed ( $3: 7$ hexanes $/ \mathrm{CH}_{2} \mathrm{Cl}_{2}$ ) to give 10 as a brown oil: $43 \mathrm{mg}$ (86\%); IR (neat) 2925, 1531, 1349, $1164 \mathrm{~cm}^{-1} ;{ }^{1} \mathrm{H}$ NMR (400 MHz) $\delta 2.92$ (m, 2H), $3.11(\mathrm{~m}, 2 \mathrm{H}), 3.76(\mathrm{~d}, J=5.6 \mathrm{~Hz}, 2 \mathrm{H}), 4.00(\mathrm{~s}, 2 \mathrm{H}), 4.95$ (dq, $J=$ 16.8 and $1.2 \mathrm{~Hz}, 1 \mathrm{H}), 5.01$ (dq, $J=10.4$ and $0.8 \mathrm{~Hz}, 1 \mathrm{H}), 5.09(\mathrm{~s}, 1 \mathrm{H})$, $5.23(\mathrm{~d}, J=10.8 \mathrm{~Hz}, 1 \mathrm{H}), 5.28(\mathrm{~s}, 1 \mathrm{H}), 5.55(\mathrm{~d}, J=17.6 \mathrm{~Hz}, 1 \mathrm{H}), 5.98(\mathrm{~m}$, $1 \mathrm{H}), 6.38(\mathrm{dd}, J=18.0$ and $11.2 \mathrm{~Hz}, 1 \mathrm{H}), 7.28(\mathrm{~m}, 2 \mathrm{H}), 7.38(\mathrm{t}, J=8.4 \mathrm{~Hz}$, 2H), $7.44(\mathrm{~d}, J=8.0 \mathrm{~Hz}, 1 \mathrm{H}), 7.50(\mathrm{t}, J=7.6 \mathrm{~Hz}, 1 \mathrm{H}), 7.71(\mathrm{~d}, J=8.4 \mathrm{~Hz}$, $2 \mathrm{H}), 7.97(\mathrm{~d}, J=8.8 \mathrm{~Hz}, 2 \mathrm{H}), 8.16(\mathrm{~d}, J=7.6 \mathrm{~Hz}, 1 \mathrm{H}), 8.32(\mathrm{~d}, J=8.8 \mathrm{~Hz}$, $2 \mathrm{H}) ;{ }^{13} \mathrm{C}$ NMR $(100.6 \mathrm{MHz}) \delta 25.2\left(\mathrm{CH}_{2}\right), 30.1\left(\mathrm{CH}_{2}\right), 47.6\left(\mathrm{CH}_{2}\right), 51.1$ $\left(\mathrm{CH}_{2}\right), 115.1(\mathrm{CH}), 116.1\left(\mathrm{CH}_{2}\right), 116.7\left(\mathrm{CH}_{2}\right), 117.9(\mathrm{C}), 118.3(\mathrm{CH})$, $119.7\left(\mathrm{CH}_{2}\right), 123.7(\mathrm{CH}), 124.4(2 \mathrm{CH}), 124.6(\mathrm{CH}), 126.4(2 \mathrm{CH}), 128.3$ (2 $\mathrm{CH}), 129.1(2 \mathrm{CH}), 129.8(\mathrm{C}), 133.6(\mathrm{CH}), 135.4(\mathrm{C}), 135.5(\mathrm{CH})$, $135.6(\mathrm{CH}), 136.5(\mathrm{C}), 138.9(\mathrm{C}), 140.4(\mathrm{C}), 144.6(\mathrm{C}), 150.0(\mathrm{C})$; ESIHRMS calcd for $\mathrm{C}_{30} \mathrm{H}_{29} \mathrm{~N}_{3} \mathrm{NaO}_{6} \mathrm{~S}_{2}: 614.1390[\mathrm{M}+\mathrm{Na}]^{+}$, found: 614.1400.

\section{RCM of triene 10}

5-Methylene-3-(4-nitrophenylsulfonyl)-9-(phenylsulfonyl)-2,3,4,8tetrahydro-1(H)-azecino[5,4-b]indole (11). A solution of triene 10 (35 mg, $0.06 \mathrm{mmol})$ and the catalyst $\mathbf{G} 2(5 \mathrm{mg}, 10 \mathrm{~mol} \%)$ in $\mathrm{CH}_{2} \mathrm{Cl}_{2}(60 \mathrm{~mL})$ was stirred at reflux overnight. The reaction mixture was concentrated and the resulting residue was chromatographed (3:7 hexanes/AcOEt) to give 11 as a yellow oil: $21 \mathrm{mg}(62 \%)$; IR (neat) $3025,2917,1530,1448,1349 \mathrm{~cm}^{-}$ 1; ${ }^{1} \mathrm{H}$ NMR (400 MHz) $\delta 2.95(\mathrm{t}, J=5.2 \mathrm{~Hz}, 2 \mathrm{H}), 3.58(\mathrm{t}, J=4.8 \mathrm{~Hz}, 2 \mathrm{H})$, $3.78(\mathrm{~d}, J=7.6 \mathrm{~Hz}, 2 \mathrm{H}), 4.24$ (br s, 2H), $5.05(\mathrm{~s}, 1 \mathrm{H}), 5.37(\mathrm{~s}, 1 \mathrm{H}), 6.16$ (d, $J=11.2 \mathrm{~Hz}, 1 \mathrm{H}), 6.39$ (dt, $J=11.2$ and $8.0 \mathrm{~Hz}, 1 \mathrm{H}), 7.04$ (dd, $J=8.0$ and $1.6 \mathrm{~Hz}, 1 \mathrm{H}), 7.09(\mathrm{td}, J=7.6$ and $1.2 \mathrm{~Hz}, 1 \mathrm{H}), 7.14(\mathrm{td}, J=8.0$ and $1.6 \mathrm{~Hz}, 1 \mathrm{H}), 7.38(\mathrm{t}, J=8.0 \mathrm{~Hz}, 2 \mathrm{H}), 7.50(\mathrm{~m}, 1 \mathrm{H}), 7.52(\mathrm{~d}, J=8.4 \mathrm{~Hz}$, $2 \mathrm{H}), 7.70(\mathrm{~d}, J=8.0 \mathrm{~Hz}, 2 \mathrm{H}), 7.81(\mathrm{~d}, J=8.4 \mathrm{~Hz}, 2 \mathrm{H}), 7.88(\mathrm{~d}, J=8.0 \mathrm{~Hz}$, $1 \mathrm{H}) ;{ }^{13} \mathrm{C}$ NMR $(100.6 \mathrm{MHz}) \delta 23.9\left(\mathrm{CH}_{2}\right), 24.0\left(\mathrm{CH}_{2}\right), 50.7\left(\mathrm{CH}_{2}\right), 55.0$ $\left(\mathrm{CH}_{2}\right), 114.7(\mathrm{CH}), 115.4\left(\mathrm{CH}_{2}\right), 115.9(\mathrm{C}), 117.7(\mathrm{CH}), 123.0(2 \mathrm{CH})$, $123.3(\mathrm{CH}), 124.4(\mathrm{CH}), 126.2(2 \mathrm{CH}), 128.4(2 \mathrm{CH}), 128.8(\mathrm{C}), 129.3(2$ $\mathrm{CH}), 131.3(\mathrm{CH}), 131.7(\mathrm{CH}), 133.7(\mathrm{CH}), 135.7(\mathrm{C}), 137.5(\mathrm{C}), 139.1(\mathrm{C})$, $143.6(\mathrm{C}), 144.7$ (C), 149.2 (C); ESI-HRMS calcd for $\mathrm{C}_{28} \mathrm{H}_{26} \mathrm{~N}_{3} \mathrm{O}_{6} \mathrm{~S}_{2}$ : 564.1258 $[\mathrm{M}+\mathrm{H}]^{+}$, found: 564.1254 .

\section{Characterization data for $14 a, 14 b, 15 a$, and $15 b$}

5-(1-Methylvinyl)-3,8-di(phenylsulfonyl)-2,3,4,7-tetrahydro-1(H)azonino[5,4-b]indole (14a). An analytical sample of 14a was obtained by additional flash chromatography of a $3: 1$ mixture of $14 \mathbf{a} / \mathbf{1 5 a}$ (entry 6 , Table 2); Yellow oil: IR (neat) 3022, 2926, 1446, $1361 \mathrm{~cm}^{-1} ;{ }^{1} \mathrm{H}$ NMR (400 $\mathrm{MHz}$, assignment aided by $\mathrm{HSQC}) \delta 1.85(\mathrm{~d}, J=0.8 \mathrm{~Hz}, 3 \mathrm{H}), 2.83(\mathrm{t}, J=$ $6.0 \mathrm{~Hz}, 2 \mathrm{H}), 3.36(\mathrm{t}, J=6.0 \mathrm{~Hz}, 2 \mathrm{H}), 4.01(\mathrm{~s}, 2 \mathrm{H}), 4.07(\mathrm{~d}, J=8.4 \mathrm{~Hz}, 2 \mathrm{H})$, $4.94(\mathrm{~s}, 1 \mathrm{H}), 5.01(\mathrm{~s}, 1 \mathrm{H}), 6.15(\mathrm{t}, J=8.4 \mathrm{~Hz}, 1 \mathrm{H}), 7.21(\mathrm{td}, J=7.6$ and $1.2 \mathrm{~Hz}, 1 \mathrm{H}), 7.27$ (td, $J=8.4$ and $1.6 \mathrm{~Hz}, 1 \mathrm{H}), 7.33(\mathrm{~d}, J=8.0 \mathrm{~Hz}, 1 \mathrm{H})$, $7.39(\mathrm{t}, J=8.0 \mathrm{~Hz}, 2 \mathrm{H}), 7.51(\mathrm{~m}, 3 \mathrm{H}), 7.57(\mathrm{~d}, J=7.2 \mathrm{~Hz}, 1 \mathrm{H}), 7.73(\mathrm{~d}, J$ $=7.6 \mathrm{~Hz}, 2 \mathrm{H}), 7.82(\mathrm{~d}, J=7.2 \mathrm{~Hz}, 2 \mathrm{H}), 8.12(\mathrm{~d}, J=8.0 \mathrm{~Hz}, 1 \mathrm{H}) ;{ }^{13} \mathrm{C}$ NMR (100.6 MHz, assignment aided by HSQC) $\delta 21.6\left(\mathrm{CH}_{3}\right), 22.3\left(\mathrm{CH}_{2}\right), 25.3$ $\left(\mathrm{CH}_{2}\right), 45.3\left(\mathrm{CH}_{2}\right), 47.7\left(\mathrm{CH}_{2}\right), 113.0\left(\mathrm{CH}_{2}\right), 114.9(\mathrm{CH}), 117.9(\mathrm{CH})$, $119.7(\mathrm{C}), 123.5(\mathrm{CH}), 124.6(\mathrm{CH}), 126.2(2 \mathrm{CH}), 127.4(2 \mathrm{CH}), 128.0$ $(\mathrm{CH}), 129.1(2 \mathrm{CH}), 129.3(2 \mathrm{C}), 129.5(\mathrm{C}), 132.7(\mathrm{CH}), 133.7(\mathrm{CH})$, $134.1(\mathrm{C}), 135.6(\mathrm{C}), 136.1(\mathrm{C}), 138.6(\mathrm{C}), 139.1$ (C), $142.8(\mathrm{C})$; ESIHRMS calcd for $\mathrm{C}_{29} \mathrm{H}_{29} \mathrm{~N}_{2} \mathrm{O}_{4} \mathrm{~S}_{2}: 533.1563[\mathrm{M}+\mathrm{H}]^{+}$, found: 533.1560 .

5-(1-Methyl-2-phenylvinyl)-3,8-(diphenylsulfonyl)-2,3,4,7-tetrahydro-1(H)azonino[5,4-b]indole (15a, mixture of Z/E isomers on the exocyclic double bond). Signals from a 3:1 mixture of 14a/15a (entry 6, Table 2). ${ }^{1} \mathrm{H}$ NMR $(400 \mathrm{MHz}$, assignment aided by HSQC, aromatic signals are not shown) $\delta 1.93(\mathrm{~d}, J=1.2 \mathrm{~Hz}, 3 \mathrm{H}$ major isomer), $2.92(\mathrm{t}, J=6.0 \mathrm{~Hz}, 2 \mathrm{H}$ major isomer), 2.98 (t, $J=6.0 \mathrm{~Hz}, 2 \mathrm{H}$ minor isomer), 3.41 (t, $J=6.0 \mathrm{~Hz}$, $2 \mathrm{H}$ major isomer), 3.54 (t, $J=6.0 \mathrm{~Hz}, 2 \mathrm{H}$ minor isomer), $4.03(\mathrm{~s}, 2 \mathrm{H}$ major isomer), $4.12(\mathrm{~d}, J=8.4 \mathrm{~Hz}, 2 \mathrm{H}$ major isomer), $5.62(\mathrm{t}, J=8.4 \mathrm{~Hz}$, $1 \mathrm{H}$ minor), 6.22 (t, $J=8.4 \mathrm{~Hz}, 1 \mathrm{H}$ major isomer), 6.48 (s, $1 \mathrm{H}$ major isomer), 6.59 (s, $1 \mathrm{H}$ minor isomer); ${ }^{13} \mathrm{C} \mathrm{NMR}(100.6 \mathrm{MHz}$, assignment aided by $\mathrm{HSQC}$, aromatic signals and quaternary carbons are not shown) $\delta 21.6\left(\mathrm{CH}_{3}\right), 22.4\left(\mathrm{CH}_{2}\right), 25.4\left(\mathrm{CH}_{2}\right), 45.8\left(\mathrm{CH}_{2}\right), 47.7\left(\mathrm{CH}_{2}\right), 127.2(\mathrm{CH})$, $128.2(\mathrm{CH})$; ESI-HRMS calcd for $\mathrm{C}_{35} \mathrm{H}_{33} \mathrm{~N}_{2} \mathrm{O}_{4} \mathrm{~S}_{2}: 609.1876[\mathrm{M}+\mathrm{H}]^{+}$, found: 609.1863.

5-(1-Methylvinyl)-3-(4-nitrophenylsulfonyl)-8-(phenylsulfonyl)-2,3,4,7tetrahydro-1(H)-azonino[5,4-b]indole (14b). An analytical sample of $\mathbf{1 4 b}$ was obtained by additional flash chromatography of a $4: 1$ mixture of 14b/15b (entry 7, Table 2); Yellow oil: IR (neat) 2925, 1530, 1448, 1348 $\mathrm{cm}^{-1} ;{ }^{1} \mathrm{H}$ NMR $(400 \mathrm{MHz}) \delta 1.88(\mathrm{~s}, 3 \mathrm{H}), 2.89(\mathrm{t}, J=6.0 \mathrm{~Hz}, 2 \mathrm{H}), 3.43(\mathrm{t}, J$ $=6.0 \mathrm{~Hz}, 2 \mathrm{H}), 4.00(\mathrm{~d}, J=8.0 \mathrm{~Hz}, 2 \mathrm{H}), 4.09(\mathrm{~s}, 2 \mathrm{H}), 4.98(\mathrm{~s}, 1 \mathrm{H}), 5.04(\mathrm{~s}$, $1 \mathrm{H}), 6.21(\mathrm{t}, J=8.0 \mathrm{~Hz}, 1 \mathrm{H}), 7.21(\mathrm{td}, J=7.6$ and $1.6 \mathrm{~Hz}, 1 \mathrm{H}), 7.31(\mathrm{~m}$, $2 \mathrm{H}), 7.39$ (t, $J=8.4 \mathrm{~Hz}, 2 \mathrm{H}), 7.51(\mathrm{t}, J=7.6 \mathrm{~Hz}, 1 \mathrm{H}), 7.74(\mathrm{~d}, J=8.8 \mathrm{~Hz}$, 2H), $7.88(\mathrm{~d}, J=8.4 \mathrm{~Hz}, 2 \mathrm{H}), 8.10(\mathrm{~d}, J=8.4 \mathrm{~Hz}, 1 \mathrm{H}), 8.26(\mathrm{~d}, J=9.2 \mathrm{~Hz}$, $2 \mathrm{H}) ;{ }^{13} \mathrm{C}$ NMR $(100.6 \mathrm{MHz}) \delta 21.6\left(\mathrm{CH}_{3}\right), 22.5\left(\mathrm{CH}_{2}\right), 25.5\left(\mathrm{CH}_{2}\right), 45.0$ $\left(\mathrm{CH}_{2}\right), 47.7\left(\mathrm{CH}_{2}\right), 113.0\left(\mathrm{CH}_{2}\right), 114.9(\mathrm{CH}), 117.8(\mathrm{CH}), 118.6(\mathrm{C}), 123.6$ 
$(\mathrm{CH}), 124.2(2 \mathrm{CH}), 124.7(\mathrm{CH}), 126.2(2 \mathrm{CH}), 128.4(2 \mathrm{CH}), 128.7(\mathrm{CH})$ 129.1 (C), $129.3(2 \mathrm{CH}), 133.8(\mathrm{CH}), 134.1$ (C), 135.7 (C), 136.0 (C) 139.0 (C), 142.9 (C), 144.5 (C), 149.9 (C); ESI-HRMS calcd for $\mathrm{C}_{29} \mathrm{H}_{28} \mathrm{~N}_{3} \mathrm{O}_{6} \mathrm{~S}_{2}: 578.1414[\mathrm{M}+\mathrm{H}]^{+}$, found: 578.1413 .

5-(1-Methyl-2-phenylvinyl)-3-(4-nitrophenylsulfonyl)-8-(phenylsulfonyl)2,3,4,7-tetrahydro-1(H)-azonino[5,4-b]indole (15b, mixture of Z/E isomers on the exocyclic double bond). Signals from a $4: 1$ mixture of $\mathbf{1 4 b} / \mathbf{1 5 b}$ (entry 7 , Table 2). ${ }^{1} \mathrm{H}$ NMR (400 MHz, aromatic signals are not shown) $\delta$ $1.94(\mathrm{~d}, J=1.2 \mathrm{~Hz}, 3 \mathrm{H}$ major isomer), 2.97 (t, $J=6.0 \mathrm{~Hz}, 2 \mathrm{H}$ major isomer), 3.49 (t, $J=6.0 \mathrm{~Hz}, 2 \mathrm{H}$ major isomer), $4.00(\mathrm{~d}, J=8.2 \mathrm{~Hz}, 2 \mathrm{H}$ major isomer), 4.21 (s, 2H major isomer), 6.27 (t, $J=8.2 \mathrm{~Hz}, 1 \mathrm{H}$ major isomer), 6.46 (s, $1 \mathrm{H}$ major isomer); ESI-HRMS calcd for $\mathrm{C}_{35} \mathrm{H}_{32} \mathrm{~N}_{3} \mathrm{O}_{6} \mathrm{~S}_{2}$ : $654.1727[\mathrm{M}+\mathrm{H}]^{+}$, found: 654.1713 .

\section{Characterization data for $18,19,20$, and 21}

5-(1-Chlorovinyl)-3-(p-toluensulfonyl)-8-(phenylsulfonyl)-2,3,4,7tetrahydro-1(H)-azonino[5,4-b]indole (18). From a 1:10 mixture of 18/19 (entry 8, Table 3$):{ }^{1} \mathrm{H}$ NMR $(400 \mathrm{MHz}$, assignment aided by HSQC aromatic protons are not shown) $\delta 2.42(\mathrm{~s}, 3 \mathrm{H}), 2.86(\mathrm{t}, J=6.0 \mathrm{~Hz}, 2 \mathrm{H})$, $3.34(\mathrm{t}, J=6.0 \mathrm{~Hz}, 2 \mathrm{H}), 3.92(\mathrm{~s}, 2 \mathrm{H}), 4.09(\mathrm{~d}, J=7.8 \mathrm{~Hz}, 2 \mathrm{H}), 5.36(\mathrm{~d}, J=$ $2.0 \mathrm{~Hz}, 1 \mathrm{H}), 5.52(\mathrm{~d}, J=2.0 \mathrm{~Hz}, 1 \mathrm{H}), 6.60(\mathrm{t}, J=7.8 \mathrm{~Hz}, 1 \mathrm{H})$. ESI-HRMS calcd for $\mathrm{C}_{29} \mathrm{H}_{28} \mathrm{ClN}_{2} \mathrm{O}_{4} \mathrm{~S}_{2}: 567.1174[\mathrm{M}+\mathrm{H}]^{+}$, found: 567.1206 .

5-(1-Chloro-2-phenylvinyl)-3-(p-toluensulfonyl)-8-(phenylsulfonyl)-2,3,4,7tetrahydro-1(H)-azonino[5,4-b]indole (19). From a 1:10 mixture of 18/19 (entry 8 , Table 3$):{ }^{1} \mathrm{H}$ NMR (400 MHz, assignment aided by HSQC) $\delta$ $2.39(\mathrm{~s}, 3 \mathrm{H}), 2.95(\mathrm{t}, J=6.0 \mathrm{~Hz}, 2 \mathrm{H}), 3.37(\mathrm{t}, J=6.0 \mathrm{~Hz}, 2 \mathrm{H}), 4.00(\mathrm{~s}, 2 \mathrm{H})$, $4.17(\mathrm{~d}, J=7.8 \mathrm{~Hz}, 2 \mathrm{H}), 6.60(\mathrm{t}, J=7.8 \mathrm{~Hz}, 1 \mathrm{H}), 6.82(\mathrm{~s}, 1 \mathrm{H}), 7.23-7.43$ $(\mathrm{m}, 10 \mathrm{H}), 7.51(\mathrm{t}, J=7.6 \mathrm{~Hz}, 1 \mathrm{H}), 7.60(\mathrm{~d}, J=7.2 \mathrm{~Hz}, 2 \mathrm{H}), 7.69(\mathrm{~d}, J=$ $8.0 \mathrm{~Hz}, 2 \mathrm{H}), 7.77(\mathrm{~d}, J=7.6 \mathrm{~Hz}, 2 \mathrm{H}), 8.13(\mathrm{~d}, J=8.4 \mathrm{~Hz}, 1 \mathrm{H}) ;{ }^{13} \mathrm{C} N M R$ $(100.6 \mathrm{MHz}) \delta 21.5\left(\mathrm{CH}_{3}\right), 22.9\left(\mathrm{CH}_{2}\right), 25.3\left(\mathrm{CH}_{2}\right), 46.3\left(\mathrm{CH}_{2}\right), 48.3\left(\mathrm{CH}_{2}\right)$, $114.9(\mathrm{CH}), 117.9(\mathrm{CH}), 119.6(\mathrm{C}), 123.5(\mathrm{CH}), 124.7(\mathrm{CH}), 126.3(2 \mathrm{CH})$, $126.5(\mathrm{CH}), 127.4(2 \mathrm{CH}), 128.0(\mathrm{CH}), 128.1(2 \mathrm{CH}), 129.3(2 \mathrm{CH}$ and $\mathrm{C})$, $129.6(2 \mathrm{CH}), 129.8(2 \mathrm{CH}), 131.7(\mathrm{CH}), 132.6(\mathrm{C}), 133.3(\mathrm{C}), 133.7(\mathrm{CH})$ 135.0 (C), 135.1 (C), 135.3 (C), 136.2 (C), 139.0 (C), 143.7 (C); ESIHRMS calcd for $\mathrm{C}_{35} \mathrm{H}_{32} \mathrm{CIN}_{2} \mathrm{O}_{4} \mathrm{~S}_{2}: 643.1487[\mathrm{M}+\mathrm{H}]^{+}$, found: 643.1491 .

(E)-5-(2-phenylvinyl)-3-(p-toluensulfonyl)-8-(phenylsulfonyl)-2,3,4,7tetrahydro-1(H)-azonino[5,4-b]indole (20). From a 1:14:2 mixture of 18/19/20 (entry 3, Table 3); ${ }^{1} \mathrm{H}$ NMR $(400 \mathrm{MHz}$, assignment aided by HSQC, aromatic protons are not shown) $\delta 2.43$ (s, 3H), 2.94 (t, $J=5.6$ $\mathrm{Hz}, 2 \mathrm{H}$ ), 3.40 (t, $J=5.6 \mathrm{~Hz}, 2 \mathrm{H}), 3.96(\mathrm{~s}, 2 \mathrm{H}), 4.11(\mathrm{~d}, J=8.2 \mathrm{~Hz}, 2 \mathrm{H})$ $6.22(\mathrm{t}, J=8.2 \mathrm{~Hz}, 1 \mathrm{H}), 6.45(\mathrm{~d}, J=16.4 \mathrm{~Hz}, 1 \mathrm{H}), 6.65(\mathrm{~d}, J=16.4 \mathrm{~Hz}$, $1 \mathrm{H})$; ESI-HRMS calcd for $\mathrm{C}_{35} \mathrm{H}_{36} \mathrm{~N}_{3} \mathrm{O}_{4} \mathrm{~S}_{2}: 626.2141\left[\mathrm{M}+\mathrm{NH}_{4}\right]^{+}$, found: 626.2136 .

2-Allyl-3-[2-\{N-(p-toluensulfonyl)amino\}ethyl]-1-(phenylsulfonyl)indole (21). Yellow oil: IR (neat) 3305, 2929, 1945, 1598, $1447 \mathrm{~cm}^{-1} ;{ }^{1} \mathrm{H}$ NMR $(400 \mathrm{MHz}) \delta 2.39(\mathrm{~s}, 3 \mathrm{H}), 2.83(\mathrm{t}, J=6.8 \mathrm{~Hz}, 2 \mathrm{H}), 3.75(\mathrm{q}, J=6.8 \mathrm{~Hz}$, $2 \mathrm{H}$ ), 3.75 (dt, $J=6.0$ and $1.2 \mathrm{~Hz}, 2 \mathrm{H}$ ), 4.27 (t, $J=6.4 \mathrm{~Hz}, 1 \mathrm{H}$ ), 4.94 (dq, $J$ $=17.2$ and $1.2 \mathrm{~Hz}, 1 \mathrm{H}), 5.01(\mathrm{dq}, J=9.6$ and $1.6 \mathrm{~Hz}, 1 \mathrm{H}), 5.96(\mathrm{~m}, 1 \mathrm{H})$, $7.20(\mathrm{~m}, 3 \mathrm{H}), 7.29(\mathrm{~m}, 2 \mathrm{H}), 7.40(\mathrm{t}, J=8.4 \mathrm{~Hz}, 2 \mathrm{H}), 7.51(\mathrm{t}, J=8.0 \mathrm{~Hz}$, $1 \mathrm{H}), 7.57(\mathrm{~d}, J=8.4 \mathrm{~Hz}, 2 \mathrm{H}), 7.70(\mathrm{~d}, J=8.8 \mathrm{~Hz}, 2 \mathrm{H}), 8.16(\mathrm{~d}, J=8.8 \mathrm{~Hz}$ $1 \mathrm{H}) ;{ }^{13} \mathrm{C}$ NMR $(100.6 \mathrm{MHz}) \delta 21.5\left(\mathrm{CH}_{3}\right), 25.0\left(\mathrm{CH}_{2}\right), 30.2\left(\mathrm{CH}_{2}\right), 42.3$ $\left(\mathrm{CH}_{2}\right), 115.2(\mathrm{CH}), 116.4\left(\mathrm{CH}_{2}\right), 117.8(\mathrm{C}), 118.3(\mathrm{CH}), 123.7(\mathrm{CH}), 124.6$ (CH), $126.3(2 \mathrm{CH}), 126.9(2 \mathrm{CH}), 129.2(2 \mathrm{CH}), 129.6(2 \mathrm{CH}), 129.7(\mathrm{C})$, $133.7(\mathrm{CH}), 135.5(\mathrm{CH}), 135.8(\mathrm{C}), 136.6(\mathrm{C}), 136.7(\mathrm{C}), 138.8(\mathrm{C}), 143.5$ (C); ESI-HRMS calcd for $\mathrm{C}_{26} \mathrm{H}_{27} \mathrm{~N}_{2} \mathrm{O}_{4} \mathrm{~S}_{2}: 495.1407[\mathrm{M}+\mathrm{H}]^{+}$, found: 495.1409 .

\section{Acknowledgements}

The authors gratefully acknowledge financial suppor for this work from the Spanish Ministerio de Economía y Competitividad, Fondos Europeos para el Desarrollo Regional (MINECOFEDER) (grant number CTQ2012-31391)

Keywords: Ring-closing enyne metathesis - ruthenium • cyclization $\cdot$ medium-sized heterocycles $\cdot$ nine-membered ring

[1] a) B. Gilbert, A. P. Duarte, Y. Nakagawa, J. A. Joule, S. E. Flores, J. A. Brissolese, J. Campello, E. P. Carrazzoni, R. J. Owellen, E. C. Blossey, K. S. Brown Jr., C. Djerassi, Tetrahedron 1965, 21, 1141. b) J. A. Joule, H. Monteiro, L. J. Durham, B. Gilbert, C. Djerassi, J. Chem. Soc. 1965 4773

[2] B. Riemer, O. Hofer, H. Greger, Phytochemistry 1997, 45, 337.

[3] P. S. Steyn, Tetrahedron 1973, 29, 107

[4] T.-S. Kam, K. Yoganathan, C.-H. Chuah, Tetrahedron Lett. 1995, 36, 759.

[5] a) G. A. Cordell in Indoles, The Monoterpenoid Indole Alkaloids, Vol. 25, (Ed.: J. E. Saxton), Wiley: New York, 1983, Part 4, Chapter 10. b) J. E. Saxton in Monoterpenoid Indole Alkaloids, Supplement to Vol. 25, (Ed.: J. E. Saxton), Wiley: Chichester, 1994, Part 4, Chapter 10.

[6] a) J. E. Saxton in Indoles, The Monoterpenoid Indole Alkaloids, Vol. 25 , (Ed.: J. E. Saxton), Wiley: New York, 1983, Part 4, Chapter 8. b) J. E. Saxton in Monoterpenoid Indole Alkaloids, Supplement to Vol. 25, (Ed. J. E., Saxton), Wiley: Chichester, 1994, Part 4, Chapter 8.

[7] A. I. Scott, C.-L. Yen, D. Greenslade, J. Chem. Soc., Chem. Commun. 1978, 947-948.

[8] For a review, see: M.-L. Bennasar in Targets in Heterocyclic Systems. Chemistry and Properties, Vol. 17 (Eds.: O. A. Attanasi, D. Spinelli), Società Chimica Italiana, Roma, Italy, 2013, pp. 35-56.

[9] a) M.-L. Bennasar, E. Zulaica, D. Solé, S. Alonso, Synlett 2008, 667. b) M.-L. Bennasar, E. Zulaica, D. Solé, S. Alonso, Tetrahedron 2012, 68, 4641. c) M.-L. Bennasar, D. Solé, E. Zulaica, S. Alonso, Tetrahedron 2013, 69, 2534

[10] a) M.-L. Bennasar, E. Zulaica, D. Solé, S. Alonso, Chem. Commun. 2009, 3372. b) M.-L. Bennasar, E. Zulaica, D. Solé, T. Roca, D. GarcíaDíaz, S. Alonso, J. Org. Chem. 2009, 74, 8359.

[11] M.-L. Bennasar, D. Solé, E. Zulaica, S. Alonso, Org. Lett. 2011, 13, 2042.

[12] M.-L. Bennasar, D. Solé, T. Roca, M. Valldosera, Tetrahedron 2015, 71, 2246.

[13] For recent synthesis of cleavamines, see: M. Amat, C. Escolano, O. Lozano, N. Llor, J. Bosch, Org. Lett. 2003, 5, 3139. See also reference 11.

[14] For recent synthesis of quebrachamine, see: a) H. K. Grover, M. A Kerr, Synlett 2015, 815. b) S.-W. Hsu, H.-Y. Cheng, A.-C. Huang, T.-L. Ho, D.-R. Hou, Eur. J. Org. Chem. 2014, 3109. c) J. E. Nidhiry, K. R. Prasad, Tetrahedron 2013, 69, 5525. d) B. Bajtos, B. L. Pagenkopf, Eur. J. Org. Chem. 2009, 1072. e) E. S. Sattely, S. J. Meek, S. J. Malcolmson, R. R. Schrock, A. H. Hoveyda, J. Am. Chem. Soc. 2009, $131,943$.

[15] For specific reviews, see: a) M. E. Maier, Angew. Chem., Int. Ed. 2000 39, 2073. b) L. Yet, Chem. Rev. 2000, 100, 2963. c) A. Michaut, J. Rodriguez, Angew. Chem., Int. Ed. 2006, 45, 5740. d) N. Blanchard, J. Eustache, in Metathesis in Natural Product Synthesis: Strategies, Substrates and Catalysts, (Eds.: J. Cossy, S. Arseniyadis, C. Meyer), Wiley-VCH, Weinheim, Germany, 2010; pp. 1-43. e) M. Tori, R. Mizutani, Molecules 2010, 15, 4242.

[16] For the synthesis of azonine rings by RCM, see: a) M. Qadir, J. Cobb, P. W. Sheldrake, N. Whittall, A. J. P. White, K. K. Hii, P. N. Horton, M. B. Hursthouse, J. Org. Chem. 2005, 70, 1552. b) R. Kaul, S. 
Surprenant, W. D. Lubell, J. Org. Chem. 2005, 70, 3838. c) D. Enders, A. Lenzen, M. Backes, C. Janeck, K. Catlin, M.-I. Lannou, J. Runsink G. Raabe, J. Org. Chem. 2005, 70, 10538.

[17] M.-L. Bennasar, T. Roca, D. García-Díaz, J. Org. Chem. 2008, 73 9033.

[18] For reviews, see: a) C. S.Poulsen, R. Madsen, Synthesis 2003, 1. b) S. T. Diver, A. J. Giessert, Chem. Rev. 2004, 104, 1317. c) S. T. Diver, J. Mol. Catal. A 2006, 254, 29. d) H. Villar, M. Frings, C. Bolm, Chem. Soc Rev. 2007, 36, 55. e) S. T. Diver, Coord. Chem. Rev. 2007, 251, 671. f) M. Mori, Adv. Synth. Catal. 2007, 349, 121.

[19] For the synthesis of 7-membered rings, see: a) J. S. Clark, G. P. Trevitt, D. Boyall, B. Stammen, Chem. Commun., 1998, 2629. b) J. S. Clark, F. Elustondo, G. P. Trevitt, D. Boyall, J. Robertson, A. J. Blake, C. Wilson, B. Stammen, Tetrahedron, 2002, 58, 1973. c) J. S. Clark, F. Elustondo, M. C. Kimber, Chem. Commun., 2004, 2470. d) M. A. Evans, J. P Morken, Org. Lett. 2005, 7, 3371. e) K. C. Majundar, H. Rahaman, R Islam, B. Roy, Tetrahedron Lett. 2006, 47, 2111. f) D. A. Kummer, J. B. Brenneman, S. F. Martin, Tetrahedron, 2006, 62, 11437. g) F.-D. Boyer I. Hanna, Org. Lett. 2007, 9, 715. h) J. S. Harvey, G. T. Giuffredi, V. Gouverneur, Org. Lett. 2010, 12, 1236. i) K. C. Majundar, RSC Adv., 2011, 1, 1152. j) L.-L. Zhang, W.-Z. Zhang, X. Ren, X.-Y. Tan, X.-B. Lu, Tetrahedron Lett. 2012, 53, 3389.

[20] For the synthesis of 8-membered rings, see: a) M. Mori, T. Kitamura, N. Sakakibara, Y. Sato, Org. Lett. 2000, 2, 543. b) E. Groaz, D. Banti, M North, Adv. Synth. Catal. 2007, 349, 142. c) E. Comer, E. Rohan, L. Deng, J. A. Porco Jr., Org. Lett. 2007, 9, 2123.

[21] a) M. Mori, T. Kitamura, Y. Sato, Synthesis 2001, 654. b) M. Lejkowski, P. Benerjee, S. Schüller, A. Münch, J. Runsink, C. Vermeeren, H.-J. Gais, Chem. Eur. J. 2015, 18, 3529

[22] Some spectroscopic features clearly differentiate $\mathbf{7 Z}$ and $\mathbf{7 E}$ (see experimental section). While the two protons of each methylene $\left(C_{1}, C_{2}\right.$, $\mathrm{C}_{4}$ and $\mathrm{C}_{7}$ ) of the nine-membered ring of $\mathbf{7 Z}$ are equal due to its high conformational flexibility, the highly rigid and twisted structure of $7 E$ makes these protons diastereotopic.
[23] See, for example: F. Nuñez-Zarur, X. Solans-Monfort, L. Rodríguez Santiago, M. Sodupe, ACS Catal. 2013, 3, 206; and references therein.

[24] M. Mori, N. Sakikabara, A. Kinoshita, J. Org. Chem. 1998, 63, 6082.

[25] a) G. C. Lloyd-Jones, R. G. Margue, J. G. de Vries, Angew. Chem. Int. Ed. 2005, 44, 7442. b) A. G. D. Grotevendt, J. A. M. Lummiss, M. L. Mastronardi, D. E. Fogg, J. Am. Chem. Soc. 2011, 133, 15918.

[26] E. C. Hansen, D. Lee, J. Am. Chem. Soc. 2004, 126, 15074.

[27] E. C. Hansen, D. Lee, J. Am. Chem. Soc. 2003, 125, 9582.

[28] J. Egger, C. Weckerle, B. Cutting, O. Schwardt, S. Rabbani, K. Lemme, B. Ernst, J. Am. Chem. Soc. 2013, 135, 9820

[29] For the use of vinyl and alkynyl halides in Pt-catalyzed cycloisomerization reactions, see: N. Chatani, N. Furukawa, H. Sakurai, S. Murai, Organometallics 1996, 15, 901.

[30] For the formation of dealkylation products in RCEYM reactions, see: $\mathrm{N}$. Dieltiens, K. Moonen, C. V. Stevens, Chem. Eur. J. 2007, 13, 203.

[31] A closely related exchange, in which the original halide is replaced by a chloride from the ruthenium catalyst, has been observed in diene RCM reactions starting from vinyl halides: M. L. Macnaughtan, J. B. Gary, D. L. Gerlach, M. J. A. Johnson, J. W. Kampf, Organometallics 2009, 28, 2880.

[32] a) T. R. Hoye, S. M. Donaldson, T. J. Vos, Org. Lett. 1999, 1, 277. b) J. J. Lippstreu, B. F. Straub, J. Am. Chem. Soc. 2005, 127, 7444.

[33] a) A. Kinoshita, M. Mori, Synlett 1994, 1020. b) E. Vedrenne, F. Royer, J. Oble, L. E. Kaïm, L. Grimaud, Synlett 2005, 2379. c) B. R. Galan, A J. Giessert, J. B. Keister, S. T. Diver, J. Am. Chem. Soc. 2005, 127, 5762. d) H. Clavier, A. Correa, E. C. Escudero-Adán, J. BenetBuchholz, L. Cavallo, S. P. Nolan, Chem. Eur. J. 2009, 15, 10244.

[34] As suggested by one of the referees, a mixture of $7 Z$ and $7 E$ could be directly formed in the propagation cycle starting from 6 . If so, the selective formation of the $Z$ stereochemistry for the overreaction product 9 might be the result of a stereochemical discrimination during the diene cross metathesis overreaction, which would be faster from the more accessible $\mathbf{7 Z}$ isomer than from $7 E$.

[35] W. C. Lee, R. H. Grubbs, Org. Lett. 2000, 2, 2145 
Entry for the Table of Contents (Please choose one layout)

Layout 1:

\section{FULL PAPER}

Ring-closing enyne metathesis: The use of RCEYM as a methodology for the construction of the nine-

membered ring of the $2,3,4,7-$

tetrahydro- $1(H)$-azonino[5,4- $b]$ indole system has been explored

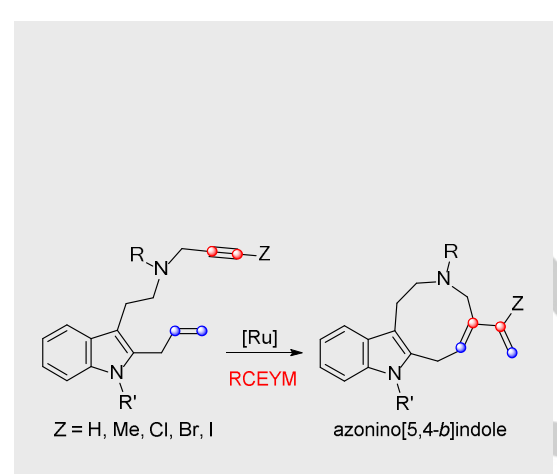

Key Topic*: Ring-closing enyne metathesis

Daniel Solé, * M.-Lluïsa Bennasar, Tomàs Roca, and Magdalena Valldosera $^{[a]}$

Page No. - Page No.

Exploration of ring-closing enyne metathesis for the synthesis of azonino[5,4- $b]$ indoles 